\title{
ANÁLISE PARA CONCEPÇÃO DE UMA ELETROVIA NA UFSM
}

\author{
César Teixeira Pacheco ${ }^{1}$ \\ Steven Andres Gutierrez Padilla ${ }^{2}$ \\ Cristiane Cauduro Gastaldini ${ }^{3}$ \\ Gustavo Lenhardt Steffen ${ }^{4}$ \\ Arthur Cordeiro Andrade 5 \\ Robson Ferreira dos Santos Júnior ${ }^{6}$
}

RESUMO: O estado do Rio Grande do Sul, segundo dados do IBGE, no ano de 2018, possuía o quarto maior PIB (produto interno bruto) per capita do Brasil [I]. Apesar de ter extrema relevância no contexto econômico brasileiro, o mesmo não pode ser afirmado quando tratamos dos carros elétricos e da eletromobilidade. Há muitos anos já se tem conhecimento que os combustíveis fósseis são limitados, ou seja, terminarão. Porém, segundo o Sindipeças, entidade que representa os fornecedores da indústria automotiva, há 45,9 milhões de automóveis em circulação no Brasil, sendo que somente 40 mil unidades têm propulsão alternativa [2]. Quando tratamos do contexto gaúcho, segundo site do Detran-RS, em 2020, o Rio Grande do Sul possuía uma frota de 186 veículos elétricos e 1.540 veículos híbridos, novamente, uma parcela muito pequena da frota total de automóveis [3]. Um dos motivos que explica o baixo número de carros elétricos no estado é o pequeno número de eletropostos instalados, sendo restritos na maioria das vezes, às maiores cidades, ou a eletropostos particulares. Para se ter uma dimensão desse baixo número de eletropostos, em toda região Noroeste do Rio Grande do Sul, não há nenhum eletroposto público, segundo o site PlugShare, com dados de 2021 [4]. Inserido neste contexto, com a intenção de fomentar o avanço da eletromobilidade em solo gaúcho, surgiu o atual artigo, com o objetivo da criação de uma eletrovia, interligando quatro campus da Universidade Federal de Santa Maria, localizados em Santa Maria, Cachoeira do Sul, Palmeira das Missões e Frederico Westphalen com a capital do Estado, Porto Alegre. Para a criação desta eletrovia, é projetada a construção de 4 eletropostos, aproveitando-se do eletroposto já construído e em funcionamento no campus da UFSM em Santa Maria, tendo como principal característica que os eletropostos contarão todos com carregadores rápidos, já que o único carregador rápido instalado no Rio Grande do Sul é o próprio de Santa Maria. Então, a partir desta nova eletrovia, com pontos de

\footnotetext{
${ }^{\mathrm{I}}$ Graduando em Engenharia Elétrica - Universidade Federal de Santa Maria - Campus Cachoeira do Sul.E-mail: cesartp22@gmail.com.

${ }^{2}$ Mestrando em Engenharia Elétrica - Universidade Estadual de Campinas - Faculdade de Engenharia Elétrica e de Computação.

${ }^{3}$ Doutora em Engenharia Elétrica - Universidade Federal de Santa Maria.

${ }^{4}$ Graduando em Engenharia Elétrica - Universidade Federal de Santa Maria - Campus Cachoeira do Sul

${ }^{5}$ Graduando em Engenharia Elétrica - Universidade Federal de Santa Maria - Campus Cachoeira do Sul

${ }^{6}$ Mestrando em Engenharia Elétrica - Universidade Federal de Santa Catarina.
} 
recarga rápida, será possível também realizar diversos estudos sobre os impactos destes carregadores, tanto para a rede local como regional. Para fomentar a utilização desta eletrovia, está prevista também a aquisição de 4 carros elétricos, sendo eles distribuídos um para cada campus da UFSM, mostrando assim a comunidade os benefícios da utilização de carros elétricos, bem como, incentivando a disseminação da eletromobilidade.

Palavras-chave: UFSM. Eletrovia. Eletromobilidade.

\section{INTRODUÇÃO}

A introdução do presente artigo busca trazer um breve contexto histórico com relação a eletromobilidade e a problemática a ser abordada pelo artigo.

Os veículos elétricos estão presentes juntos à comunidade desde o século XIX, quando em I835 Thomas Davenport construiu e demonstrou o primeiro veículo elétrico, que andava sobre trilhos. Desde lá, incontáveis avanços contribuíram para que a tecnologia fosse desenvolvida e chegasse até os dias atuais, como promessa de eficiência e combate à poluição. As melhorias se deram em todas as áreas dos veículos elétricos, como baterias, aerodinâmica, melhora na eficiência dos motores, aumento da tecnologia embarcada, entre outros. Porém durante este período, os veículos movidos a partir de motores de combustão interna dominaram e continuam dominando o mercado global, devido aos seus custos e a sua maior autonomia.

A eletromobilidade surge a partir das mudanças nos meios de produção e da necessidade de alternativas com relação à tratativa dos seres humanos sobre o meio ambiente. Nos últimos anos, o aumento na frota de veículos e os problemas relacionados a eles, como a sobrecarga de vias e a limitação de fluxo, a poluição sonora, atmosférica e visual, vem necessitando de alternativas para minimizar essas problemáticas que impactam direta e indiretamente a saúde, a segurança e o bemestar da população. Uma alternativa plausível e cada vez mais cotidiana é a adoção da eletromobilidade, possível graças aos avanços tecnológicos, evidenciando uma tendência mundial com relação a uma visão mais sustentável no uso dos transportes.

As vendas de carros elétricos chegaram a 2,1 milhões globalmente em 2019. As vendas aumentaram $6 \%$ em relação a 2018 , após vários anos de crescimento anual de vendas de carros elétricos. A participação de carros elétricos no mercado global atingiu um novo recorde de 2,6\%, ante $2,4 \%$ em 2018 e $1 \%$ em 2017. O estoque de carros elétricos, portanto, aumentou $40 \%$ ano a ano em 2019, indicando um forte desenvolvimento sustentado do setor de VE (Veículos Elétricos). A China é o maior mercado do mundo (I,06 milhão carros elétricos vendidos em 2019), seguido pela Europa (560.00o) e os Estados Unidos (326.00o). Essas três regiões foram responsáveis por mais de $90 \%$ de todas as vendas em 2019 [5].

A Noruega é o país com maior participação de mercado para vendas $(56 \% \mathrm{em}$ 2019), seguida pela Islândia (23\%) e os Países Baixos (15\%). Carros elétricos com baterias representaram uma parcela maior das vendas de carros elétricos em 2019. $O$ progresso na descarbonização do setor de energia irá acelerar os benefícios de redução de emissões de $\mathrm{CO}_{2}$ dos $\mathrm{VE}^{\prime} \mathrm{s}$ [5].

Pesquisas mostram que os carros elétricos são melhores para o meio ambiente. Eles emitem menos gases do efeito estufa e poluentes do ar em comparação com os carros 
movidos a gasolina ou a diesel. E isso leva em consideração sua produção e geração de eletricidade para mantê-los funcionando. O principal benefício dos carros elétricos é a contribuição que podem dar para a melhoria da qualidade do ar nas cidades. Sem escapamento, os carros elétricos puros não produzem emissões de dióxido de carbono ao dirigir. Isso reduz consideravelmente a poluição do ar. Em um ano, apenas um carro elétrico nas estradas pode economizar em média I,5 milhão de gramas de $\mathrm{CO}_{2}$. Isso é o equivalente a quatro voos de ida e volta de Londres para Barcelona.

No Brasil, há diversos prós e contras a serem levados em conta quando tratamos da eletromobilidade, aspectos extremamente positivos e incentivadores e problemáticas que atrasam a inserção da eletromobilidade na população em geral, consideramos abaixo os principais pontos a serem levados em conta.

Tabela or - Prós e Contras da Eletromobilidade

\begin{tabular}{|l|l|}
\hline Prós & Contras \\
\hline $\begin{array}{l}\text { Políticas Públicas e incentivos à } \\
\text { eletromobilidade }\end{array}$ & Problemas de infraestrutura \\
\hline $\begin{array}{l}\text { Indústria automotiva já instalada } \\
\text { recursos }\end{array}$ & Uso de Combustíveis renováveis \\
\hline $\begin{array}{l}\text { Grande disponibilidade de fontes de } \\
\text { energia renovável de matérias primas e }\end{array}$ & $\begin{array}{l}\text { Características muito específicas do } \\
\text { mercado automotivo nacional }\end{array}$ \\
\hline Matriz energética limpa & anos \\
\hline
\end{tabular}

Fonte: https://www.senaipr.org.br/tecnologiaeinovacao/blog/afinal-o-que-e-eletromobilidade-I36287-42695o.shtml> [6]

Ou seja, a inserção da eletromobilidade ainda necessita vencer algumas barreiras impostas pela realidade brasileira. Um dos contras que puderam ser visualizados na Tabela or é com relação à infraestrutura, pois para que os usuários consigam se locomover utilizando veículos elétricos, é necessário que existam eletropostos suficientes para a demanda de recarga destes veículos.

Mas para instalação dessas estruturas, é necessário locais públicos, com um certo espaço, infraestrutura e segurança, onde também é possível realizar pesquisas de melhorias e também com certa instrução para novos usuários, e que melhor local que abrange todas essas características se não as universidades públicas? 


\section{I.I Problema a ser abordado}

Uma das dificuldades encontradas pela mobilidade elétrica atualmente é a baixa densidade de eletropostos disponíveis, dificultando viagens de longas distâncias com veículos elétricos, que estão no processo de aumento de autonomia, com melhora nas baterias e na eficiência dos motores, por exemplo. Essa falta de pontos de recarga, é ainda mais visível no Rio Grande do Sul, onde estão situados os 4 campus da Universidade Federal de Santa Maria, objetos de estudo deste artigo.

Por isso, hoje é de interesse social, acadêmico, e até de infraestrutura, que as universidades públicas sejam utilizadas como cobaias, a fim de testar, melhorar e instruir a população com relação ao carregamento dos VE's (Veículos Elétricos).

No estado do Rio Grande do Sul não é diferente, o estado avança a passos largos rumo a eletromobilidade, com diversos incentivos fiscais, como por exemplo a isenção fiscal do poder público estadual referente ao imposto sobre a propriedade de veículos automotores (IPVA) para proprietários de veículos elétricos, investimentos em infraestruturas, sendo que o estado desponta como um dos principais polos brasileiros que iniciam a transição para a mobilidade elétrica sustentável.

Nesse sentido, as universidades do estado possuem papel fundamental para esta transição, principalmente uma universidade que possui uma vasta área de abrangência, impactando diversos municípios, considerada uma universidade estratégica nacional, a primeira universidade federal fora de uma capital, com mais de 25 mil alunos, essa é a Universidade Federal de Santa Maria.

A universidade já começou a sua transição, com um eletroposto de recarga rápida, e com a aquisição de um carro movido a energia elétrica, mas imagina ter uma universidade desse porte totalmente estruturada para receber a eletromobilidade, com seus quatro campi com um eletroposto, com toda sua frota, 95 automóveis, Io vans, 6 micro ônibus, 17 ônibus e 13 caminhões, movidos a energia elétrica, além do incentivo a população local para aquisição de veículos com esse tipo de alimentação, é nesse sentido que o presente artigo se estrutura.

O presente artigo, busca fazer uma análise da viabilidade da maior inserção da eletromobilidade na Universidade Federal de Santa Maria, conectando os seus quatro campi, cada um com um eletroposto, além de conectar a universidade a capital do 
estado, Porto Alegre, a cidade mais habitada do estado, sendo a origem da maioria de servidores e discentes da universidade, buscando também analisar a rota, a demanda, os prós e contras, as dificuldades, entre outros pontos, lembrando que esta é uma análise inicial, mas que visa introduzir diversas outras pesquisas futuras referente a eletromobilidade na universidade.

\section{A UFSM}

Neste tópico será exposto uma visão geral sobre a Universidade Federal de Santa Maria (UFSM), com seu contexto histórico, o seu contexto atual, o campus de Cachoeira do Sul, a origem da maioria dos estudantes do presente artigo, o seu Plano de Desenvolvimento Institucional (PDI 2016-2026), as usinas solares atuais e futuras da instituição e o Centro de Excelência em Energia e Sistemas de Potência (CEESP), o desenvolvedor da eletromobilidade atual no Campus Sede da instituição.

\section{I Contexto histórico da Universidade}

A Universidade Federal de Santa Maria foi fundada em 196o, com o apoio de diversas figuras marcantes no cenário político nacional, foi o marco inicial na interiorização das universidades públicas brasileiras, pois a mesma foi a primeira universidade fora do eixo das capitais dos estados no Brasil.

A formalização ocorreu através de uma emenda no artigo 16 do projeto de lei que foi a voto no Congresso Nacional e tornou-se a Lei 3.838-C, recebendo o apoio do vice-presidente João Goulart, do presidente Juscelino Kubitschek, do senador Daniel Krieger, dentre tantas outras figuras da época.

A lei em questão afirmava que a Universidade seria constituída dos seguintes estabelecimentos: "as faculdades de Medicina, de Farmácia e de Odontologia, e o Instituto Eletrotécnico, do Centro Politécnico. Seria, ainda, integrada dos seguintes estabelecimentos particulares de ensino superior ou de alto padrão, na situação de agregados: Faculdade de Direito, Faculdade de Filosofia, Ciências e Letras Imaculada Conceição; Faculdade de Ciências Políticas e Econômicas; e a Escola de Enfermagem Nossa Senhora Medianeira" [7]. 
Imagem or - Lançamento do Centro Politécnico

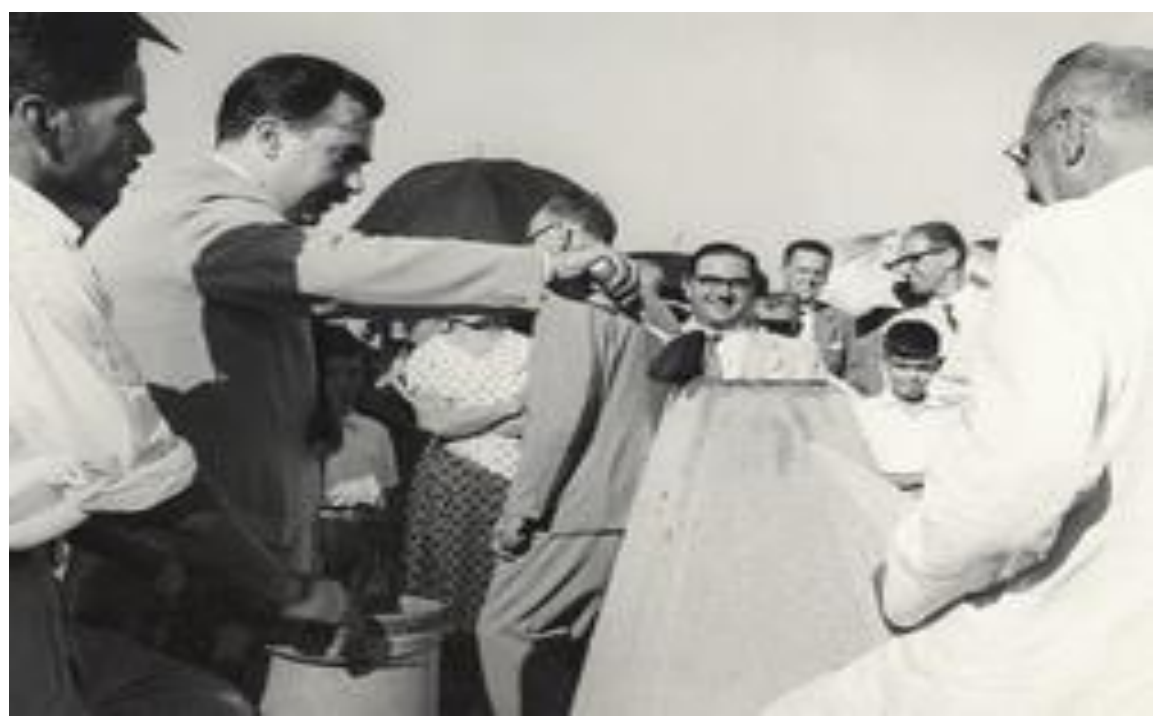

Fonte: $<$ http://coral.ufsm.br/revista/numeroo2/registroo4.html $>[7]$

A lei foi datada em I4 de dezembro de 1960, mas a sanção em si ocorreu apenas em I8 de dezembro de 1960, em ato público realizado na sacada do Palácio das Esmeraldas, sede do Governo do estado de Goiás, pelo até então presidente Juscelino Kubitschek, e a publicação no Diário Oficial da União ocorreu no dia 20 de dezembro, mas a comemoração do aniversário da universidade é apenas celebrada na data que a Lei da universidade foi registrada, ou seja, no dia 14 de dezembro de 1960, sendo que a instituição atualmente possui 6o anos.

Imagem 02 - Instalação oficial da UFSM

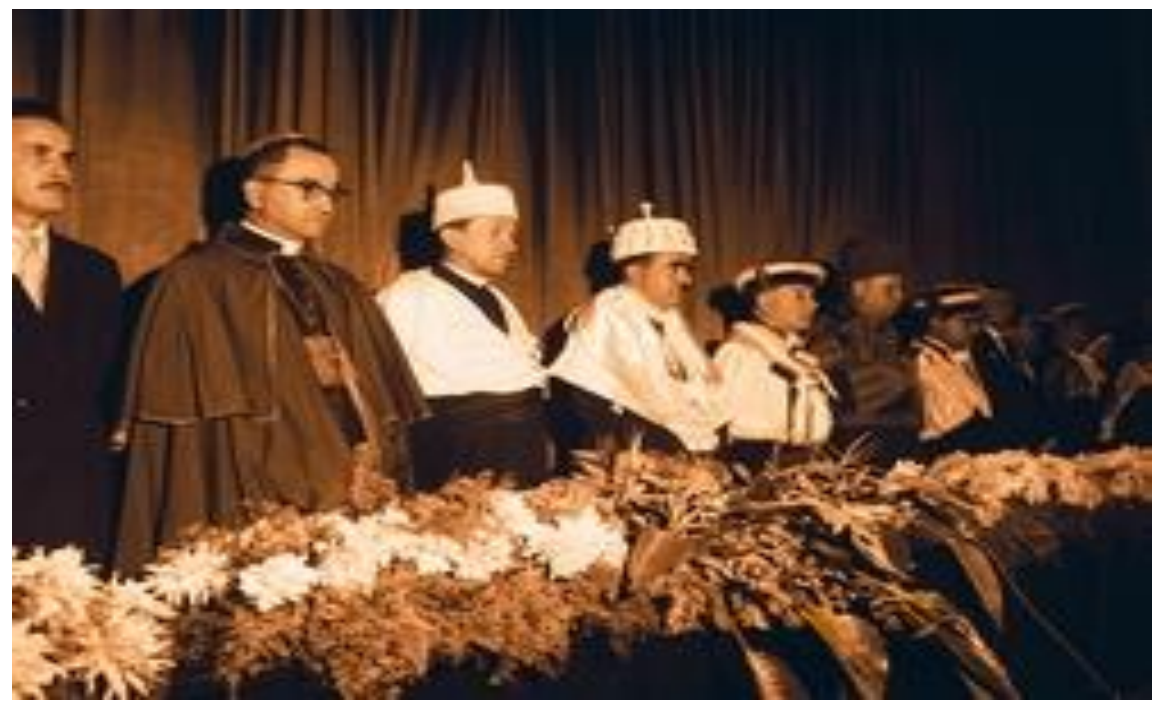

Fonte: 〈http://coral.ufsm.br/revista/numeroos/cronologiaz.html> [7] 
"Na cerimônia especial de fundação, o reitor fundador, professor José Mariano da Rocha Filho proferiu um longo discurso afirmando a importância da iniciativa educacional para a região. $\mathrm{Na}$ mesma solenidade, foi anunciada a outorga do título de Doutor Honoris Causa ao deputado federal Tarso Dutra e ao senador Daniel Krieger, pelo empenho de ambos na criação da Universidade" [7].

Imagem 03 - Instalação solene da UFSM

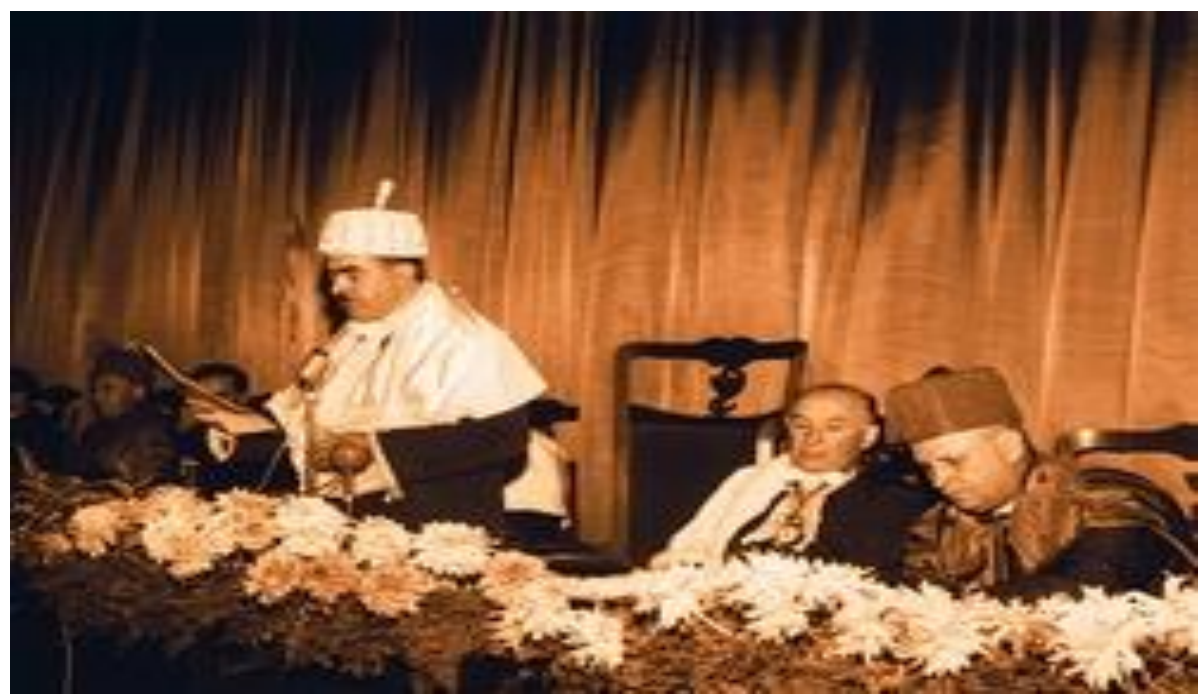

Fonte: 〈http://coral.ufsm.br/revista/numeroos/cronologiaz.html> [7]

\subsection{Contexto atual da UFSM}

A universidade atualmente continua entregando a excelência que se espera de uma universidade federal brasileira, pública, gratuita e de qualidade, com sua sede localizada no bairro Camobi, $\mathrm{km}$ 9, rodovia RS-509, sendo que a grande maioria das atividades acadêmicas e administrativas ficam no campus Sede, na cidade de Santa Maria-RS, mas também existem campus fora da cidade sede.

No campus sede em Santa Maria, atualmente são ofertados 89 cursos de graduação, 8 em Frederico Westphalen, 7 em Palmeira das Missões, 6 em Silveira Martins, 5 em Cachoeira do Sul, além de 12 cursos de graduação na modalidade EAD. A universidade possui atualmente uma área construída de 281.6I4 metros quadrados em ritmo de crescimento, pois já há um planejamento para aumentar a abrangência e o impacto da universidade no estado.

A instituição possui 25 auditórios com capacidade total para acomodar 4.177 pessoas. Nas dependências da UFSM, há duas agências bancárias; uma do Banco do 
Brasil e uma da Caixa Econômica Federal e um posto dos Correios, doze lancherias e dois Restaurantes Universitários, Biblioteca Central, com 92.535 volumes (livros e teses), Bibliotecas Setoriais, com 63.783 volumes (livros e teses), Espaço Multiuso para sediar eventos de grande porte, Hospital-Escola, com 335 leitos, Hospital Veterinário e Farmácia-Escola Comercial, Museus e Planetário.

A UFSM oferece, ainda, área residencial, mediante cadastro socioeconômico realizado pela Pró-Reitoria de Assuntos Estudantis, com a capacidade para alojar até I.805 estudantes, embora tal disponibilidade dependa de alguns fatores, a instituição é referência neste quesito. Além da moradia, os alunos cadastrados podem pleitear auxílio transporte, alimentação, ensino de língua estrangeira, bolsa de assistência e monitoria remunerada. Devido à existência da universidade, a cidade de Santa Maria é conhecida como Cidade Universitária.

Atualmente a instituição conta com 25.783 estudantes, 2.028 docentes, 2.630 Técnicos-Administrativos em educação [8], os estudantes estão distribuídos na instituição, com a grande maioria no nível de graduação, da seguinte maneira.

Gráfico or - Alunos por nível e modalidade

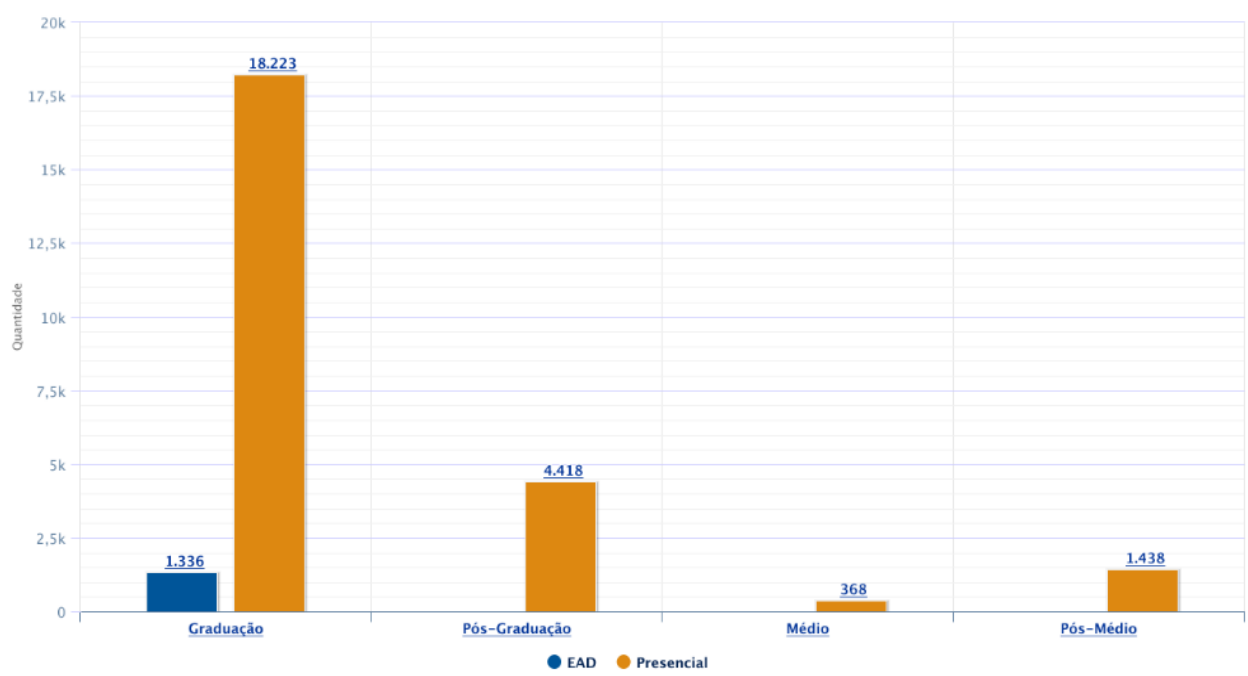

Fonte: $<$ https://portal.ufsm.br/ufsm-em

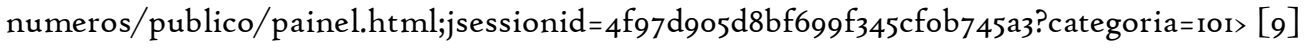


No gráfico abaixo é apresentado a distribuição dos servidores (docentes e técnicos administrativos) nas unidades de ensino.

Gráfico 02 - Servidores por unidade de ensino

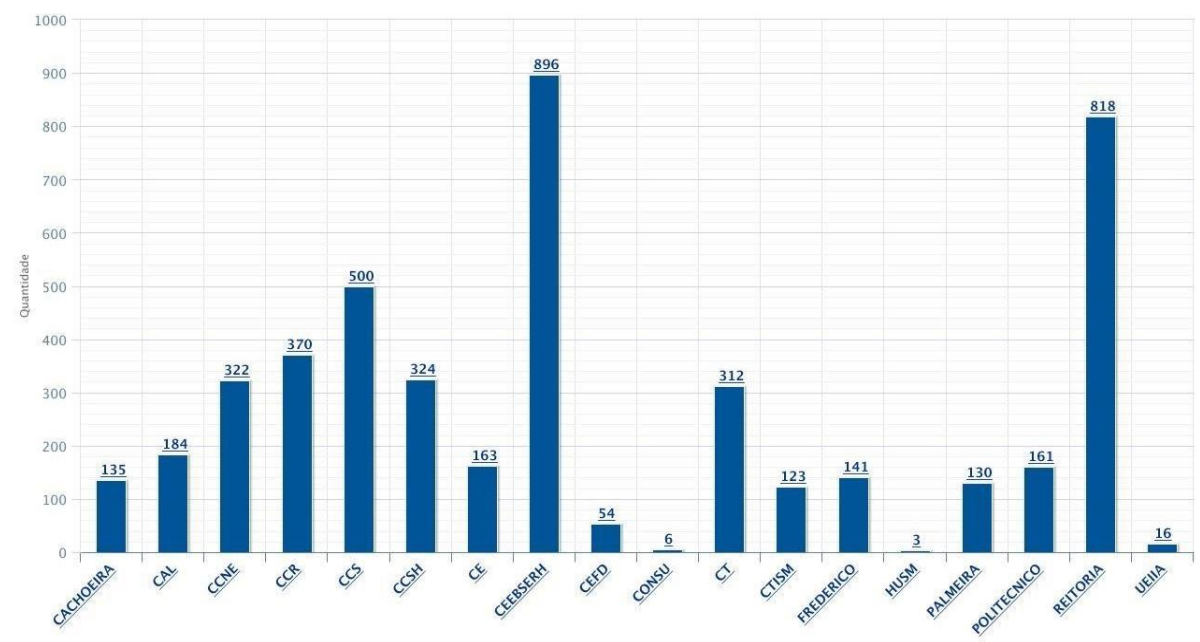

Fonte:<https://portal.ufsm.br/ufsm-em

numeros/publico/painel.html;jsessionid $=4 \mathrm{f}_{97} \mathrm{~d} 905 \mathrm{~d} 8 \mathrm{bf6} 69 \mathrm{f}_{345} \mathrm{cfob}_{745 \mathrm{a}}$ ?categoria $=$ Ior $>$ [9]

As unidades de ensino: Cachoeira, Frederico e Palmeira são os campus fora de sede. As demais unidades de ensino estão localizadas no campus sede, isto, é, na cidade de Santa Maria. No gráfico abaixo é apresentado a distribuição dos alunos com vínculo ativo em cursos presenciais nas unidades de ensino.

Gráfico 03 - Alunos com vínculo ativo

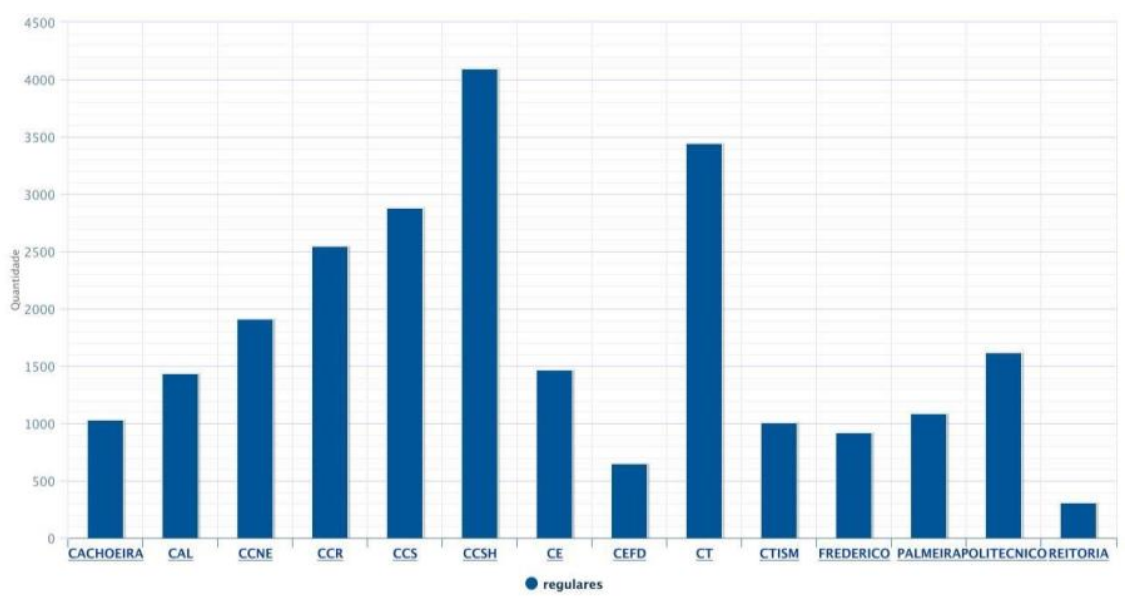

Fonte: $<$ https://portal.ufsm.br/ufsm-em-

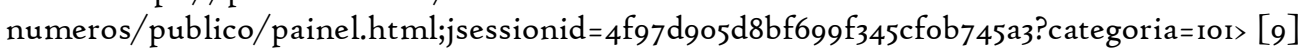




\subsection{UFSM em Cachoeira do Sul}

As universidades de ensino superior passaram por um processo de expansão muito marcante, e na UFSM não foi diferente. Aliado ao desejo da população cachoeirense, o movimento "Vem, UFSM" mobilizou a cidade, a universidade e o governo. Tanto que em agosto de 20II, o desejo do tripé citado anteriormente foi atendido, sendo que a presidenta Dilma Rousseff anunciou a criação do Campus UFSM em Cachoeira do Sul (UFSM-CS), através do programa Reuni (Reestruturação e Expansão das Universidades Federais).

Após todos os trâmites legais, o campus recebeu a nomeação dos responsáveis pela implementação do Campus, como Diretor e Vice-Diretor pro tempore, os professores José Mário Doleys Soares e Hilton Abílio Gründiling, respectivamente.

As aulas se iniciaram em II de agosto de 2014, sendo que 9 dias depois houve a solenidade oficial de inauguração do Campus, com a presença de diversas autoridades, de Cachoeira do Sul, da UFSM Campus Sede, como o Reitor Paulo Burmann (Autoridade discursando na Imagem 4), do Governo do Estado, além de servidores, professores, alunos da UFSM-CS e a comunidade em geral.

Imagem 04 - Solenidade de Inauguração do Campus UFSM-CS

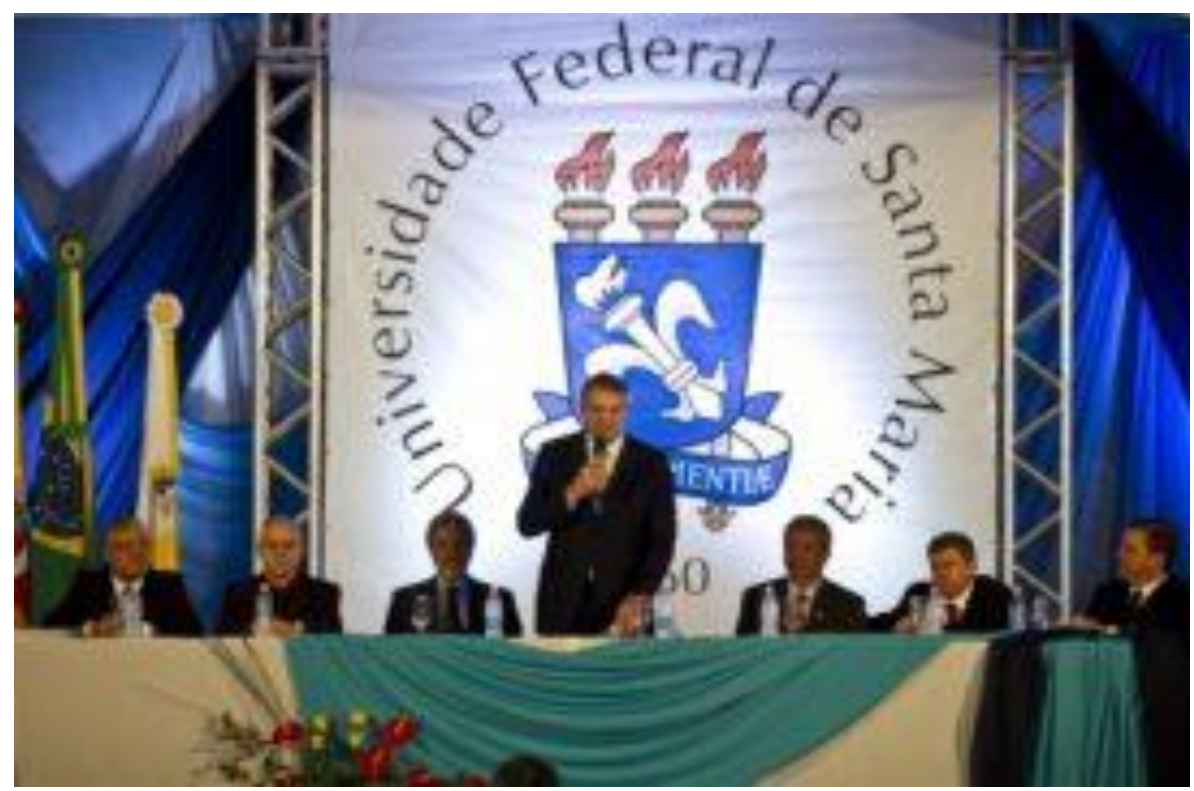

Fonte: $\langle$ http://coral.ufsm.br/midia/?p=20132> [1o] 
Após a solenidade, houve uma carreata até as instalações do Campus, onde representantes da UFSM e da comunidade desataram a fita na entrada do prédio e descerraram a placa inaugural do novo Campus.

Em 2017, ocorreu a primeira consulta para a Direção do Campus Cachoeira do Sul. Assim, em 2018, os professores Rogério Brittes da Silva e Lucas Delongui assumiram os cargos de Diretor e Vice-diretor da UFSM-CS.

O Campus da UFSM - Cachoeira do Sul iniciou suas atividades com cinco cursos de graduação: Arquitetura e Urbanismo, Engenharia Agrícola, Engenharia Elétrica, Engenharia Mecânica e Engenharia de Transportes e Logística, com um total de 190 alunos ingressando semestralmente.

O projeto proposto para o Campus da UFSM em Cachoeira do Sul leva em conta as necessidades científicas e tecnológicas do Rio Grande do Sul e do Brasil ao concentrar esforços na área das Engenharias. Assim, a expectativa é de que esse Campus da UFSM se torne um centro de referência nacional em ensino, pesquisa e extensão nas áreas das Engenharias, Arquitetura e Tecnologias da Informação.

\subsection{PDI 2016-2026 da UFSM}

O Plano de Desenvolvimento Institucional da UFSM (PDI 2016-2026) foi elaborado com base em consulta à comunidade. Este documento apresenta as Diretrizes das Políticas Institucionais relacionadas aos seguintes tópicos: planejamento e avaliação institucional; governança, controle interno e gestão de riscos; organização administrativa; gestão de pessoas; gestão orçamentária; tecnologia de informação; assistência estudantil; infraestrutura; gestão ambiental; comunicação, acessibilidade; inovação, empreendedorismo e transferência de tecnologias.

\subsection{Projetos de Eficiência Energética}

A RGE e a Universidade Federal de Santa Maria (UFSM) concluíram e três de cinco projetos de Pesquisa e Desenvolvimento iniciados em 2016 e orçados em $\mathrm{R} \$$ 6,5 milhões pela CPFL Energia, contemplando ações inovadoras de eficiência energética e gestão da operação da rede elétrica.

Em outubro de 2018, a Usina de Microgeração Solar Fotovoltaica, instalada no campus sede da UFSM, entrou em funcionamento. Possuindo roo $\mathrm{kW}$ de potência, 
com capacidade para fornecer energia para os prédios próximos à sua localização. Além da usina, este projeto viabilizou a substituição, por lâmpadas de LED, de I,3 mil lâmpadas fluorescentes em salas de aula e espaços internos e 56 lâmpadas de vapor de sódio da Avenida Roraima.

$\mathrm{Na}$ seqüência do projeto, foi instalada uma Central de Monitoramento de Eficiência Energética, de onde os operadores podem acompanhar a geração de energia fotovoltaica e o funcionamento do sistema de iluminação da Avenida Roraima.

Possibilitando, assim, aproveitar melhor a usina de geração solar instalada e realizar uma gestão eficiente dos pontos internos de climatização e luminosidade. Neste projeto, foram investidos cerca de $\mathrm{R} \backslash \$ \mathrm{I}$ milhão e possuía como previsão inicial a economia de $\mathrm{R} \backslash \$ 150$ mil anual na conta de energia.

Em 2019, foram instalados medidores de energia individualizados nas diferentes unidades acadêmicas e conectados à Central de Monitoramento, o que permitiu uma otimização dos recursos.

Imagem o5 - Usina de Microgeração Solar Fotovoltaica - ıookW

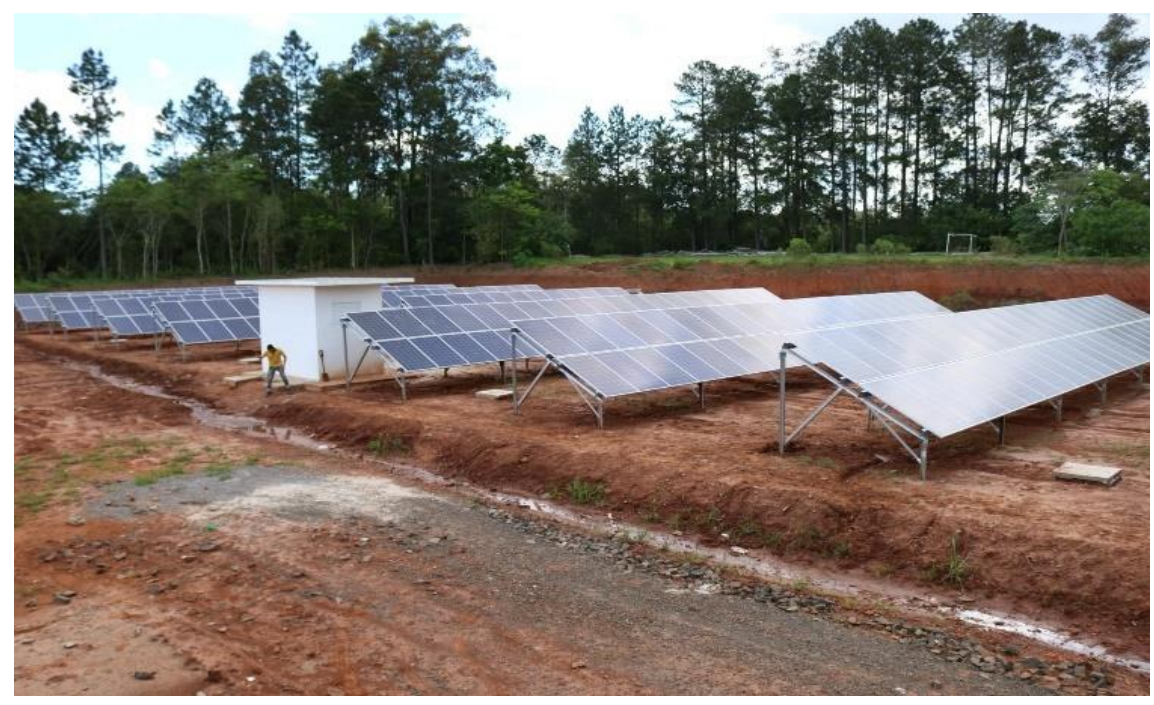

Fonte: https://www.ufsm.br/2018/ro/31/ufsm-e-rge-sul-inauguram-usina-de-microgeracao-solarfotovoltaica/> [II]

Os projetos desenvolvidos contribuíram para a montagem de um laboratório vivo de testes das soluções desenvolvidas no Campus da UFSM, agregando medidores inteligentes de energia, religadores, bancos capacitores e até mesmo controle de sistema de iluminação pública, sendo toda esta infraestrutura coberta por 
uma rede de comunicação de longo alcance e baixo consumo de energia, chamada LoRaWan.

Em termos acadêmicos, o estudo e conhecimento gerado resultou na publicação de mais de 30 artigos científicos da UFSM em eventos nacionais e internacionais, livros, teses de doutorado, dissertações de mestrado e dois registros de softwares no INPI. Atualmente, a UFSM é a $25^{\underline{a}}$ universidade mais sustentável do Brasil pelo GreenMetric no ano passado, a UFSM tem investido cada vez mais em fontes de energia renováveis.

Em 2021, a universidade conseguiu investimento para a implementação de mais duas usinas fotovoltaicas: uma no campus sede e outra em Cachoeira do Sul. O recurso veio em parte do Ministério da Educação (MEC), no valor de $\mathrm{R} \backslash \$ \mathrm{I}, 5$ milhão. A segunda parte, no mesmo valor, é proveniente de recursos próprios.

A usina contará com uma estação de medição de temperatura e irradiância, e os dados da usina serão integrados ao supervisório energético da UFSM. Em Santa Maria, a usina será implantada no Centro de Eventos, ao lado do Pavilhão Polivalente, com $5.852 \mathrm{~m}^{2}$ de área. O campus de Cachoeira do Sul terá sua primeira usina fotovoltaica, com área de $10.307 \mathrm{~m}^{2}$. Cada uma delas tem $400 \mathrm{~kW}$ de potência instalada.

A estimativa é que a nova usina do campus sede vai gerar uma economia de até $\mathrm{R} \backslash \$ 40$ mil por mês, tendo de três a quatro anos para recuperação do investimento. A energia gerada será injetada na rede elétrica gerando créditos, que serão utilizados posteriormente para abater no valor total de energia consumida pela universidade.

O processo licitatório foi realizado em 2020 e a Ownergy foi empresa vencedora. O projeto executivo já foi elaborado e a previsão para a conclusão das instalações é para outubro de 2021, com início do funcionamento imediato.

\subsection{CEESP e seu projeto de eletromobilidade na UFSM Campus Santa Maria}

O Centro de Excelência em Energia e Sistemas de Potência (CEESP) é um grupo de pesquisa sediado no Centro de Tecnologia da Universidade Federal de Santa Maria (CT-UFSM) e cadastrado no Diretório de Grupos do CNPq. Suas 
atividades iniciaram em 1986, tendo sido reconhecido oficialmente pelo Conselho do CT-UFSM em 1989 sendo um dos seus Grupos de Pesquisa mais produtivos e ativos - na ocasião o grupo tinha a denominação de Núcleo de Desenvolvimento de Micro centrais (NUDEMI). A partir do ano 2000 o nome NUDEMI foi substituído por Centro de Estudos em Energia e Meio Ambiente (CEEMA). Recentemente o grupo adotou o nome CEESP por congregar também um número significativo de pesquisadores que atuam na área de sistemas elétricos de potência.

O CEESP está atualmente sediado no Centro de Tecnologia da UFSM sendo que a maior parte de suas instalações estão localizadas num amplo conjunto de laboratórios (Eletrônica Leve, Eletrônica Industrial, Montagens Eletromecânicas, Processamento da Energia, Célula de Combustível, Modelamento de Fontes de Energia, Redes Elétricas Inteligentes (Lab Smart Grid), Laboratório de Proteção, Laboratório de Energia e Sistemas de Potência). A área experimental encontra-se em um terreno localizado em uma das avenidas principais do Campus da UFSM. Nesta área são realizados os ensaios de campo e aplicações experimentais do aproveitamento da energia geotérmica. Utilizando-se de uma respeitável infraestrutura de pesquisa montada com recursos próprios e doações ao longo dos vinte e sete anos de sua existência, o CEESP tem demonstrado cada vez maior de cooperação com outros organismos como o Instituto Politécnico de Kiev (Ucrânia), a Colorado School of Mines (Estados Unidos) e INESC-PORTO.

Atualmente um importante projeto em andamento pelo CEESP é INTERFACE DE INOVAÇÃO MULTI AGENTE ENVOLVENDO A INDÚSTRIA AUTOMOBILÍSTICA, OS SISTEMAS DE ENERGIA E INFRAESTRUTURAS DE MOBILIDADE ELÉTRICA PARA ELETROVIAS INTELIGENTES, coordenado pela Profa. Dra. Luciane Neves Canha. Este projeto possibilitou a aquisição de possui uma estação de carregamento de veículos elétricos com os seguintes tipos: $\mathrm{ABB}$ de $7 \mathrm{~kW}$, Juice $7 \mathrm{~kW}$ e $\mathrm{ABB}$ de $50 \mathrm{~kW}$. O ABB de $7 \mathrm{~kW}$ custou cerca de $\mathrm{R} \$ \mathrm{i} 6$ mil, o Juice $7 \mathrm{~kW}$ em torno de $\mathrm{R} \$ 8$ mil e o $\mathrm{ABB}$ de $50 k \mathrm{~W}$ (Terra 54 DC Fast Charger), foi adquirido por $\mathrm{R} \$ 205$ mil. 


\section{Imagem 06 - Eletroposto na UFSM Campus Sede}

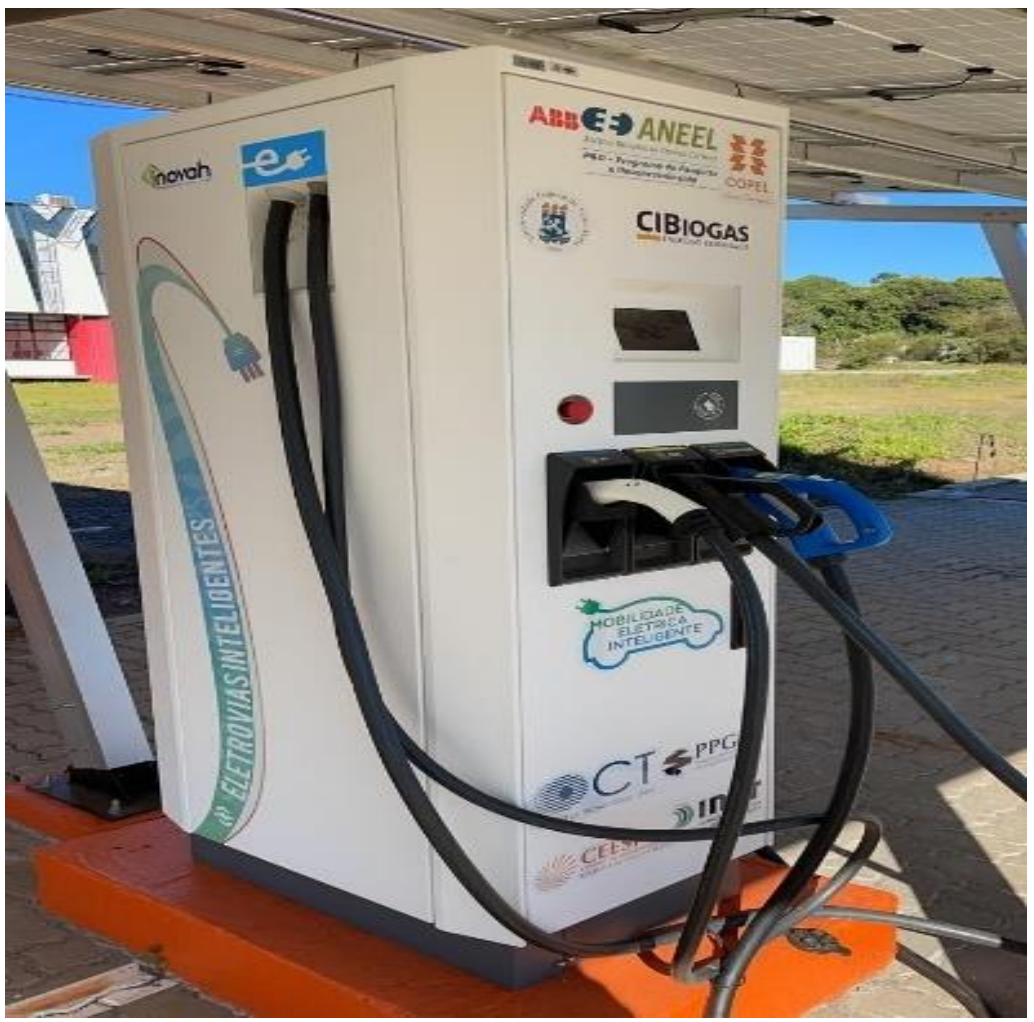

Fonte: Os autores.

\section{Imagem 07 - Tempo de Carga}

\begin{tabular}{|c|c|c|c|c|c|c|c|}
\hline & & \multicolumn{6}{|c|}{ Charging time (minutes) } \\
\hline & & \multirow{2}{*}{$\begin{array}{c}\mathbf{5 0} \mathbf{~ k W} \\
\text { Terra 54 } \\
\text { Terra 54HV }\end{array}$} & \multirow[t]{2}{*}{$\begin{array}{c}90 \mathbf{k W} \\
\text { Terra } 94\end{array}$} & \multicolumn{2}{|c|}{$\begin{array}{c}120 \mathbf{k W} \\
\text { Terra } 124\end{array}$} & \multicolumn{2}{|c|}{$\begin{array}{c}180 \mathbf{k W} \\
\text { Terra } 184\end{array}$} \\
\hline & & & & $2 \mathrm{EVs}$ & $1 \mathrm{EV}$ & $2 \mathrm{EVs}$ & $1 \mathrm{EV}$ \\
\hline \multirow{3}{*}{ ड़ } & $\begin{array}{l}60 \mathrm{kWh} \text { BEV } \\
400 \mathrm{VDC}\end{array}$ & 50 & 25 & 40 & 20 & 25 & 13 \\
\hline & $\begin{array}{l}90 \mathrm{kWh} \text { BEV } \\
400 \mathrm{VDC}\end{array}$ & 70 & 40 & 60 & 30 & 40 & 20 \\
\hline & $\begin{array}{l}100 \mathrm{kWh} \text { BEV } \\
800 \mathrm{VDC}\end{array}$ & 80 & 45 & 65 & 33 & 45 & 22 \\
\hline \multirow{4}{*}{ 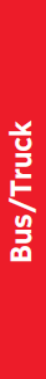 } & $\begin{array}{l}120 \mathrm{kWh} \text { BEV } \\
\text { School Bus } \\
400 \text { VDC }\end{array}$ & 95 & 53 & 80 & 40 & 55 & 26 \\
\hline & $\begin{array}{l}150 \text { kWh BEV } \\
\text { Delivery Van } \\
800 \text { VDC }\end{array}$ & 120 & 65 & 100 & 50 & 65 & 33 \\
\hline & $\begin{array}{l}200 \text { kWh BEV } \\
\text { Work Truck } \\
800 \text { VDC }\end{array}$ & 160 & 88 & 133 & 66 & 88 & 44 \\
\hline & $\begin{array}{l}300 \text { kWh BEV } \\
60 ' \text { Transit Bus } \\
800 \text { VDC }\end{array}$ & 240 & 130 & 200 & 100 & 130 & 66 \\
\hline
\end{tabular}

Fonte: $\langle$ https://search.abb.com/library/Download.aspx? DocumentID=9AKKIo799IA4246\&Language Code $=$ en $\&$ DocumentPartId $=\&$ Action $=$ Launch $>[12]$ 


\section{PROPOSTA}

Neste momento, o presente documento apresenta todas as características da proposta do artigo, como os ODS que o artigo abrange e uma breve contextualização da proposta.

\section{I Objetivos de Desenvolvimento Sustentável (ODS)}

Os Objetivos de Desenvolvimento Sustentável (ODS) foram definidos, em 2015, pela Organização das Nações Unidas (ONU), compondo I7 objetivos principais, com I69 metas, a fim de guiar a construção e efetivação de políticas públicas que tem por objetivo conduzir o desenvolvimento da humanidade de forma sustentável até 2030.

De acordo com a Plataforma Agenda 2030 "ao adotarem o documento “Transformando o Nosso Mundo: A Agenda 2030 para o Desenvolvimento Sustentável” (A/70/L.I), os países comprometeram-se a tomar medidas ousadas e transformadoras para promover o desenvolvimento sustentável nos próximos is anos sem deixar ninguém para trás”.

O tema desses objetivos são os abrangentes possíveis, a fim de contemplar todos os países do mundo, baseados em cinco perspectivas fundamentais: pessoas, planeta, prosperidade, parceria e paz.

Sobre as temáticas inseridas nesses objetivos, podemos destacar a erradicação da pobreza, segurança alimentar, agricultura, saúde, educação, igualdade de gênero, redução das desigualdades, energia, água e saneamento, padrões sustentáveis de produção e de consumo, mudança do clima, cidades sustentáveis, proteção e uso sustentável dos oceanos e dos ecossistemas terrestres, crescimento econômico inclusivo, infraestrutura, industrialização, entre outros, é possível visualizar no esquema a seguir, os ODS inseridos em diferentes áreas temáticas. 
Imagem 08 - Esquema das ODS inseridas em cada área

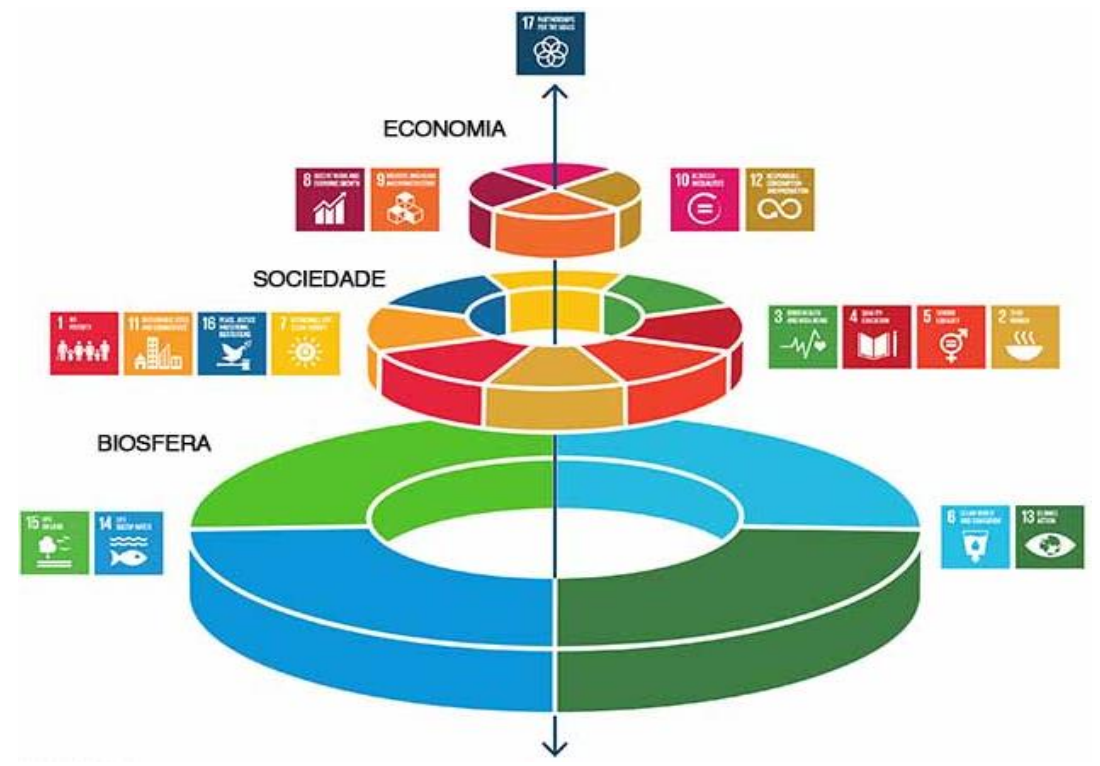

Fonte: $\langle$ http://www.agenda2030.org.br/os_ods/> [13]

Com relação ao Brasil, o país vem discutindo e definindo prioridades para com os ODS desde 2013, sendo um dos principais pontos a ser priorizado pelo país a erradicação da pobreza, mas de acordo com o site Pacto Global, "no contexto atual, se nada for replanejado, apenas o ODS 7 (Energia Limpa e acessível) será alcançado pelo Brasil em 2030" [I4].

O presente artigo então, abrange os $\operatorname{ODS}_{3,7,8,9}$ e $13 . \mathrm{O}$ ODS 3 traz o objetivo de "saúde e bem-estar", um dos benefícios dos carros elétricos, pois com a diminuição das emissões de $\mathrm{CO}_{2}$, a tendência é que se diminua a poluição e consequentemente as doenças respiratórias, muito recorrentes em pessoas que moram nos grandes centros atualmente. Já o ODS 7 traz o objetivo "Energia Limpa e Acessível", um objetivo totalmente atrelado ao contexto da eletromobilidade, que traz uma forma de mobilidade sustentável.

Os ODS 8 e 9 tratam da indústria e crescimento econômico, sendo que países que investem neste novo modo de mobilidade estão na frente para possuírem um maior destaque frente aos outros países, e não é diferente com relação às empresas.

E o ODS 13 traz o objetivo "Ação contra a mudança global do clima”, sendo esta meta também impactada pela eletromobilidade, pois com a diminuição das 
emissões de $\mathrm{CO}_{2}$, diminui-se o efeito estufa por exemplo, assim contribuindo para atenuar esta problemática que traz o objetivo sustentável número 13. Portanto, observamos a importância do presente artigo, pois o impacto social, econômico e principalmente ambiental, é consideravelmente grande.

\subsection{Contextualização da proposta}

Os campus se localizam nas cidades de: Santa Maria (campus sede), Cachoeira do Sul, Palmeira das Missões e Frederico Westphalen, cidades localizadas no centro e norte do Estado.

\section{Imagem 09 - Localização dos Campus no Estado}

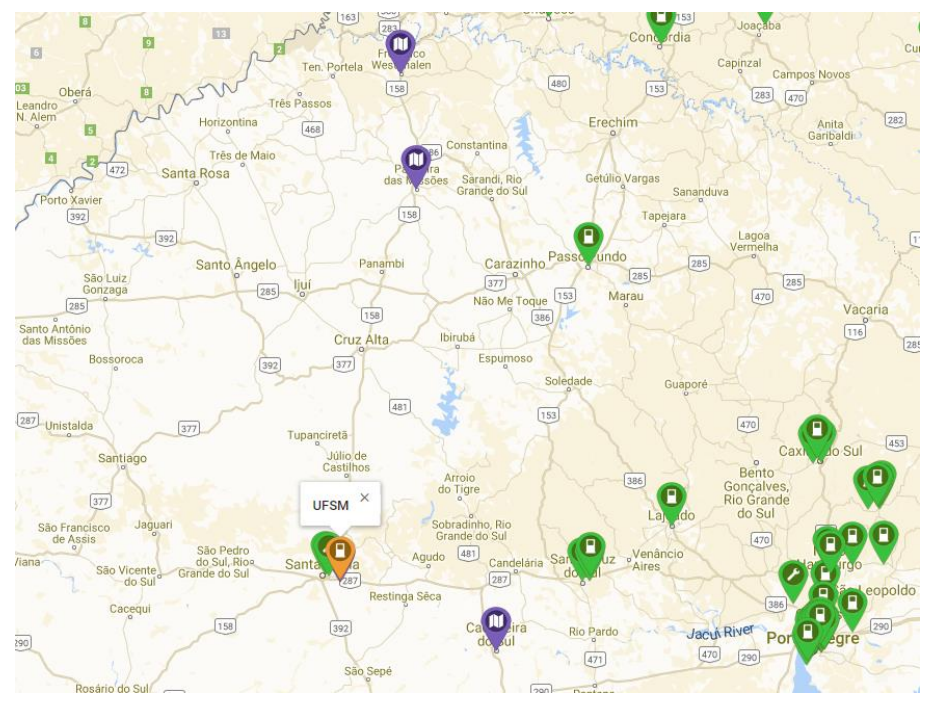

Fonte: $\langle$ https://www.plugshare.com/> [4]

A partir da imagem 09, é possível verificar que das cidades mencionadas anteriormente, somente Santa Maria possui pontos de recarga públicos (destaque em laranja na Imagem o9), o que inviabiliza uma viagem com o carro elétrico entre os campus.

A falta destes pontos de recarga, reduz o investimento em eletromobilidade nestas regiões, que poderiam ser altamente exploradas, visto que o tráfego, principalmente de caminhões, é muito intenso nesta região, para o escoamento da produção de milho e soja. Então a Universidade, que tem como um de seus pilares, impactar a comunidade ao seu redor, tem como objetivo ser pioneira na implementação de eletropostos, de maneira específica eletropostos de recarga rápida. 
Com a intenção de fomentar a implementação e utilização destes pontos de recarga, estão previstos também recursos para a compra de quatro carros elétricos, um para cada campus, para que se possa realizar o tráfego entre campus com o carro elétrico. Estes eletropostos serão interligados com a geração de energias renováveis, amplamente difundida na UFSM, possuindo hoje uma planta solar fotovoltaica no campus sede, e sendo construída também uma usina no campus de Cachoeira do Sul.

Com os avanços tecnológicos da eletromobilidade e os investimentos atuais da UFSM em energias renováveis, associados à inserção de eletropostos e carros elétricos, contribuirá tanto em pesquisas que agregarão novos conhecimentos para esse tipo de tecnologia quanto para impactar a comunidade com os benefícios da mobilidade elétrica.

\section{OBJETIVOS}

Neste próximo tópico são apresentados os objetivos gerais e específicos do artigo.

\section{I Objetivo Geral}

Projetar estações de recarga elétrica entre os campi UFSM e Porto Alegre com foco no uso de fontes renováveis.

\subsection{Objetivos Específicos}

- Realizar pesquisas sobre métodos e alternativas de recarga de veículos elétricos por meio de fontes renováveis de energia.

- Realizar estudos técnicos e ambientais para implantação de postos de recarga de veículos elétricos.

- Estabelecer a estimativa de custo necessária para o projeto e construção da eletrovia.

- Determinação de leis ambientais, regulamentos e licenças para a construção das estações.

- Realizar o projeto das estações de recarga de veículos elétricos utilizando uma das alternativas investigadas.

\section{JUSTIFICATIVA}

A população mundial está cada vez mais residindo em cidades. Cerca de 51\% ou 3,5 bilhões de pessoas atualmente vivem em áreas urbanas e em 2050 a tendência é 
chegar a 70\% da população ou 6,3 bilhões de pessoas. A mobilidade urbana é um dos desafios mais difíceis que as cidades enfrentam. Hoje, $64 \%$ de todos os quilômetros percorridos são urbanos e espera-se que percursos dentro de áreas urbanas tripliquem até 2050 .

Ser capaz de se locomover em áreas urbanas de forma rápida, conveniente e com pouco impacto ambiental é fundamental para a sociedade. Os sistemas de mobilidade existentes estão próximos de entrar em colapso. Em 2050, o tempo médio que um morador urbano passa em engarrafamentos serão Io6 horas por ano, três vezes mais do que hoje.

Os baixos níveis de motorização e a expectativa de aumento de renda resultam em uma frota de veículos leves de 130 milhões de unidades em 2050. Dessa forma, a taxa de motorização alcança aproximadamente i,6 habitante/autoveículo em 2050, patamar equivalente ao observado em países da Organização para a Cooperação e Desenvolvimento. Certamente, há um desafio subjacente relacionado aos limites sustentáveis de expansão de uso da frota nas cidades, ligadas às políticas de mobilidade urbana.

A resposta a essas questões dependerá, fundamentalmente do desenvolvimento tecnológico e da efetividade e abrangência de aplicação da Política Nacional de Mobilidade Urbana como observado na imagem io.

Imagem Io - Crescimento da emissão de gases, horas no trânsito e investimento em mobilidade
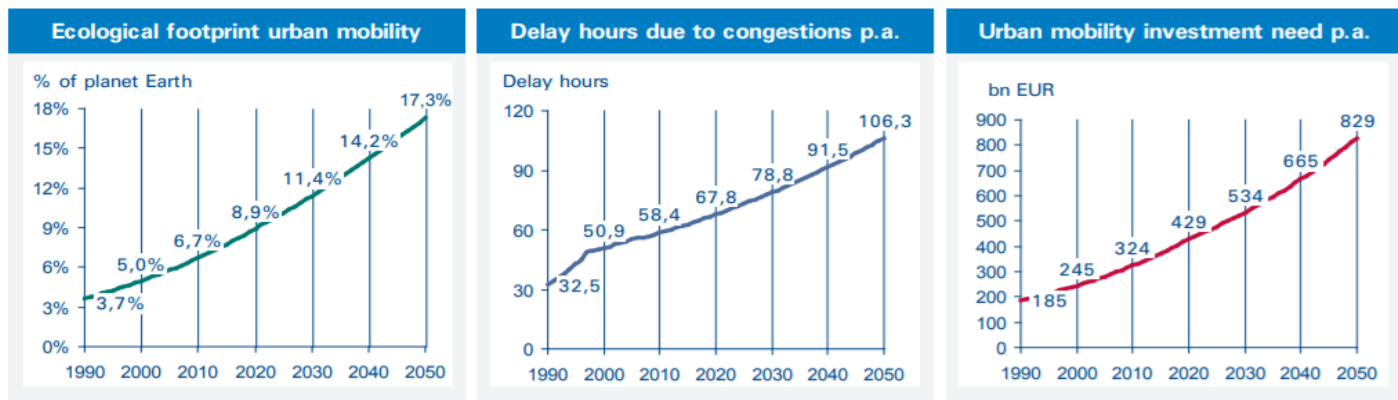

Fonte: $<$ http://repository.unipiloto.edu.co/handle/20.500.12277/5045> [15]

Tendo em vista o grande aumento da frota de veículos e consequentemente o aumento do consumo de energia, é necessário um alto investimento em outras fontes de energia, preferencialmente as fontes de energias renováveis. 
O Brasil, atualmente, tem $83 \%$ de sua matriz elétrica originada de fontes renováveis, de acordo com o Ministério de Minas e Energia [16]. A participação é liderada pela hidrelétrica $(63,8 \%)$, seguida de eólica $(9,3 \%)$, biomassa e biogás $(8,9 \%)$ e solar centralizada $(\mathrm{I}, 4 \%)$.

Considerando as fontes não renováveis, a matriz energética brasileira tem grande parte de sua produção proveniente de fontes reináveis, o que coloca o país entre os principais países do mundo quando o assunto é energia proveniente de fontes renováveis. Em 2019 a matriz energética representada na imagem II mostra a disposição das fontes que compõem a matriz energética no país.

Imagem II - Matriz energética brasileira

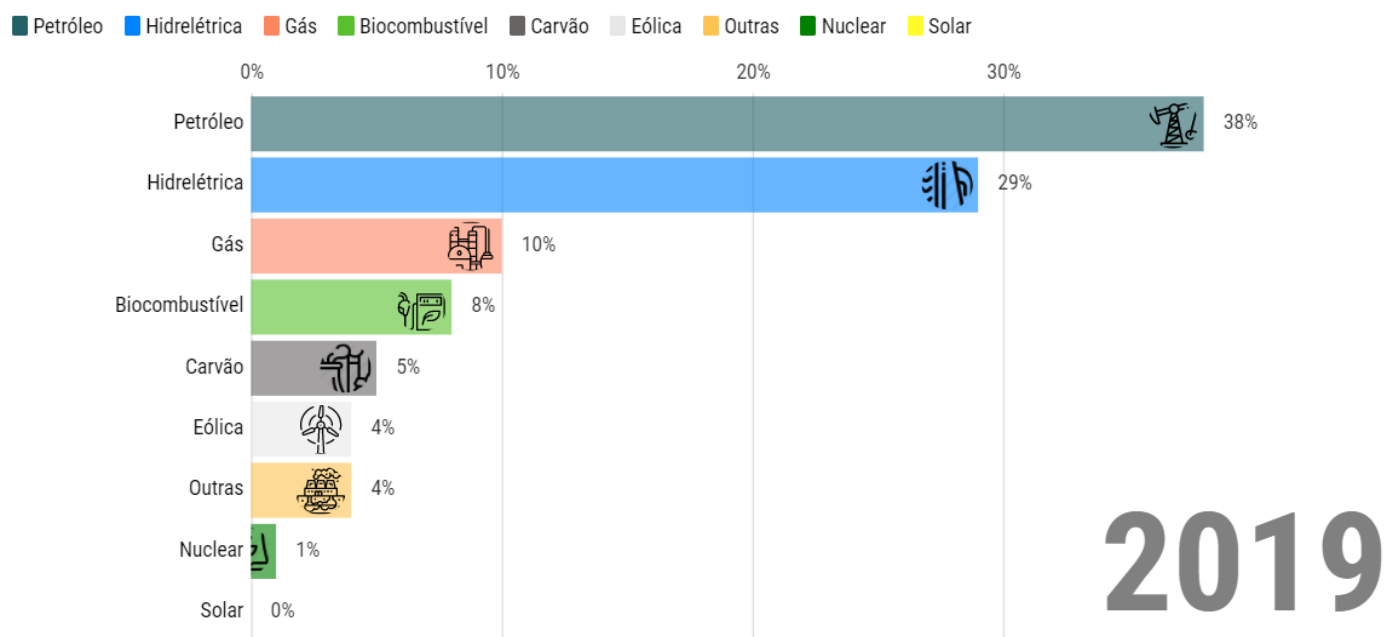

Fonte: 〈https://www.epe.gov.br/pt> [17]

Das energias renováveis, pode-se observar um aumento expressivo em fontes como eólica, solar e de biocombustíveis como pode ser observado na imagem I2.

Imagem 12 - Distribuição das Fontes Renováveis

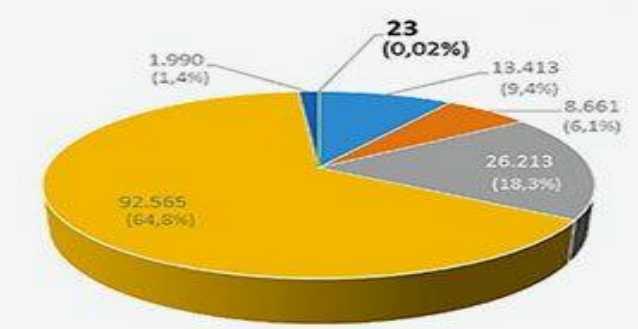

MATRIZATUAL 2016 (MW)

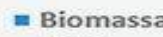

= Hídrica

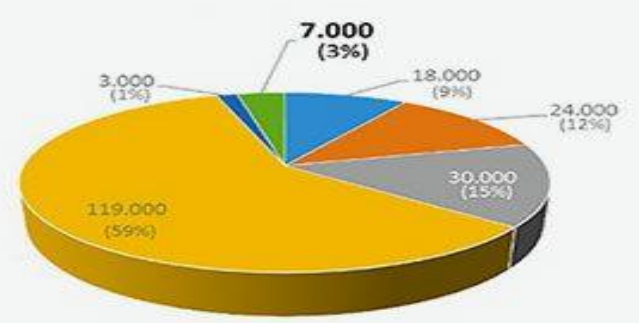

PREVISÃO MATRIZ 2024 (MW)

Fonte: $\langle$ https://www.epe.gov.br/pt> [17] 
Levando em consideração as informações acima mencionadas, uma saída para ambos os desafios citados é o investimento em veículos elétricos (VE's). As vendas de carros elétricos chegaram a 2,I milhões globalmente em 2019. As vendas aumentaram 6\% em relação a 2018, após vários anos de crescimento anual de vendas de carros elétricos. A participação de carros elétricos no mercado global atingiu um novo recorde de 2,6\%, ante 2,4\% em 2018 e $1 \%$ em 2017. O estoque de carros elétricos, portanto, aumentou $40 \%$ ano a ano em 2019, indicando um forte desenvolvimento sustentado do setor de VE (Veículos Elétricos).

A China é o maior mercado do mundo ( $\mathrm{I}, 06$ milhão carros elétricos vendidos em 2019), seguido pela Europa (560.00o) e os Estados Unidos (326.00o). Essas três regiões foram responsáveis por mais de $90 \%$ de todas as vendas em 2019. A Noruega é o país com maior participação de mercado para vendas ( $56 \backslash \%$ em 2019), seguida pela Islândia (23\%) e os Países Baixos (I5\%). Carros elétricos a bateria representaram uma parcela maior das vendas de carros elétricos em 2019. O progresso na descarbonização do setor de energia irá acelerar os benefícios de redução de emissões de $\mathrm{CO}_{2}$ dos VEs. A imagem 13 mostra o cenário mundial.

Imagem 13 - Vendas de Veículos Elétricos no Mundo

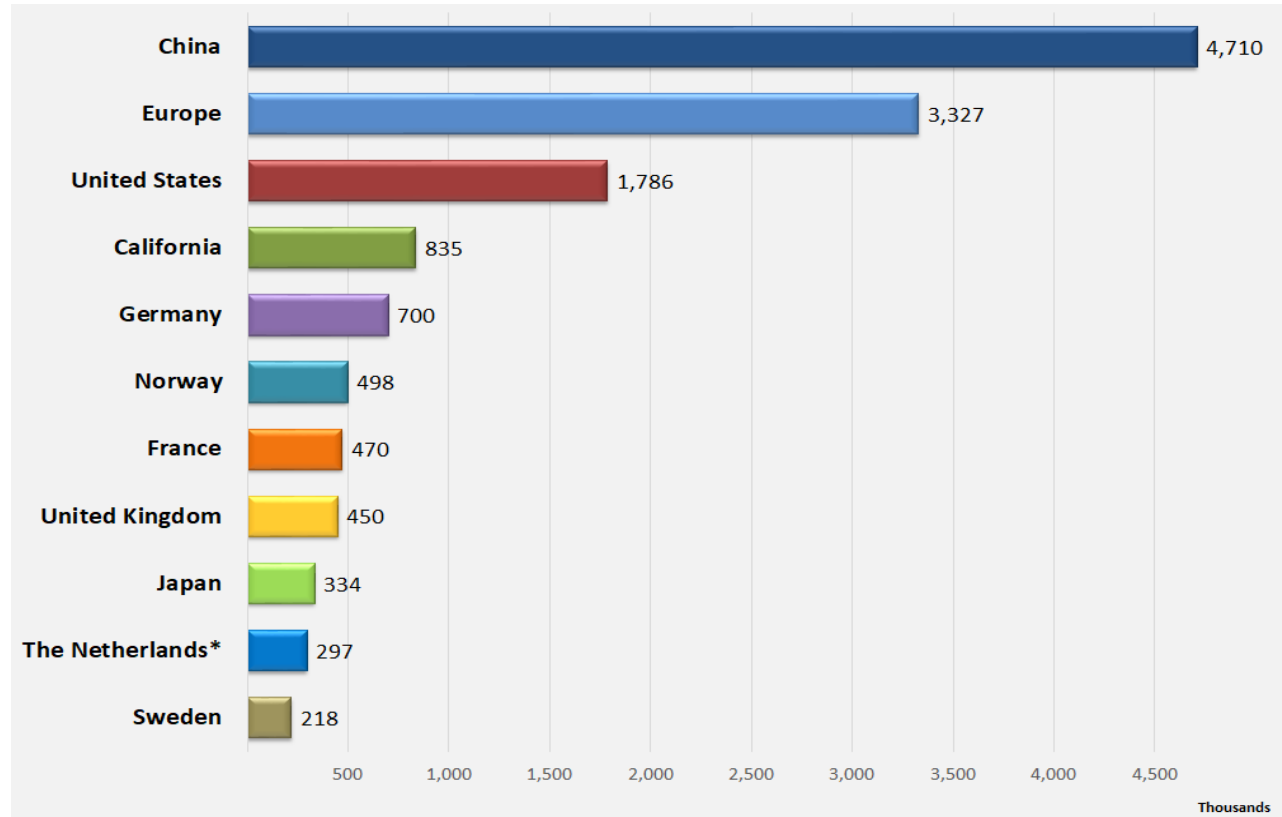

Fonte: https://www.temsustentavel.com.br/energia-renovavel-destaque-em-2or6/> [18] 
Pesquisas mostram que os carros elétricos são melhores para o meio ambiente. Eles emitem menos gases do efeito estufa e poluentes do ar do que os carros a gasolina ou a diesel. E isso leva em consideração sua produção e geração de eletricidade para mantê-los funcionando, a imagem i4 traz um panorama entre os veículos elétricos e os movidos à gasolina, comparando seu custo por milhas rodados.

Imagem 14 - Custo-benefício dos carros elétricos

\section{EFICIENCIA ELETRICA}

Gastando o mesmo valor, carros elétricos percorrem distâncias até dez vezes maiores que um carro a gasolina

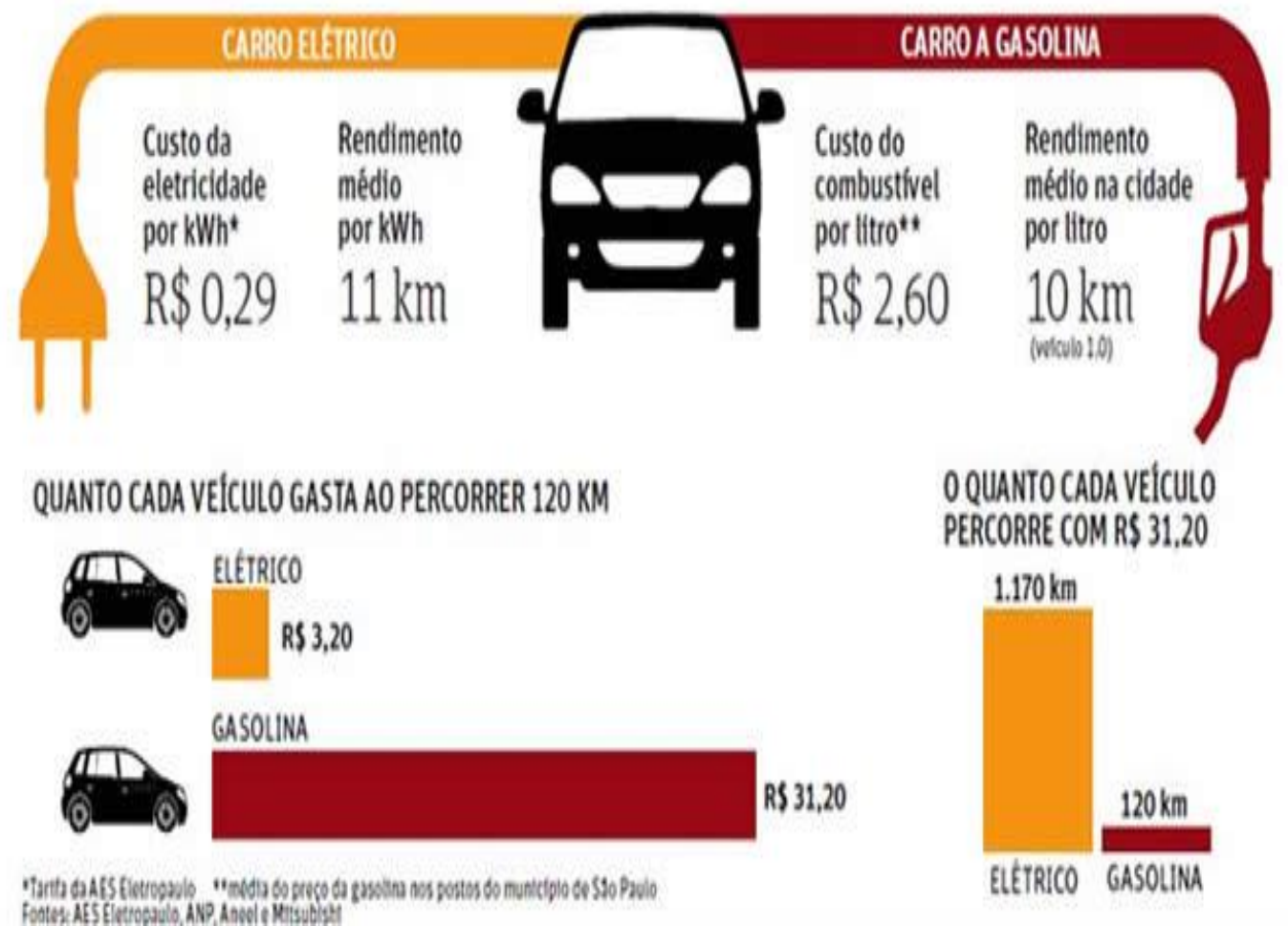

Fonte: $<$ http://repository.unipiloto.edu.co/ $>$ [19]

O principal benefício dos carros elétricos é a contribuição que podem dar para a melhoria da qualidade do ar nas cidades. Sem escapamento, os carros elétricos puros não produzem emissões de dióxido de carbono ao dirigir. Isso reduz consideravelmente a poluição do ar. Em um ano, apenas um carro elétrico nas estradas pode economizar em média I,5 milhão de gramas de $\mathrm{CO}_{2}$. Isso é o equivalente a quatro voos de ida e volta de Londres para Barcelona. A imagem is mostra um comparativo entre sobre a redução de emissão de $\mathrm{CO}_{2}$ entre veículos movidos à gasolina e elétricos. 
Imagem 15 - Custo-benefício dos carros elétricos

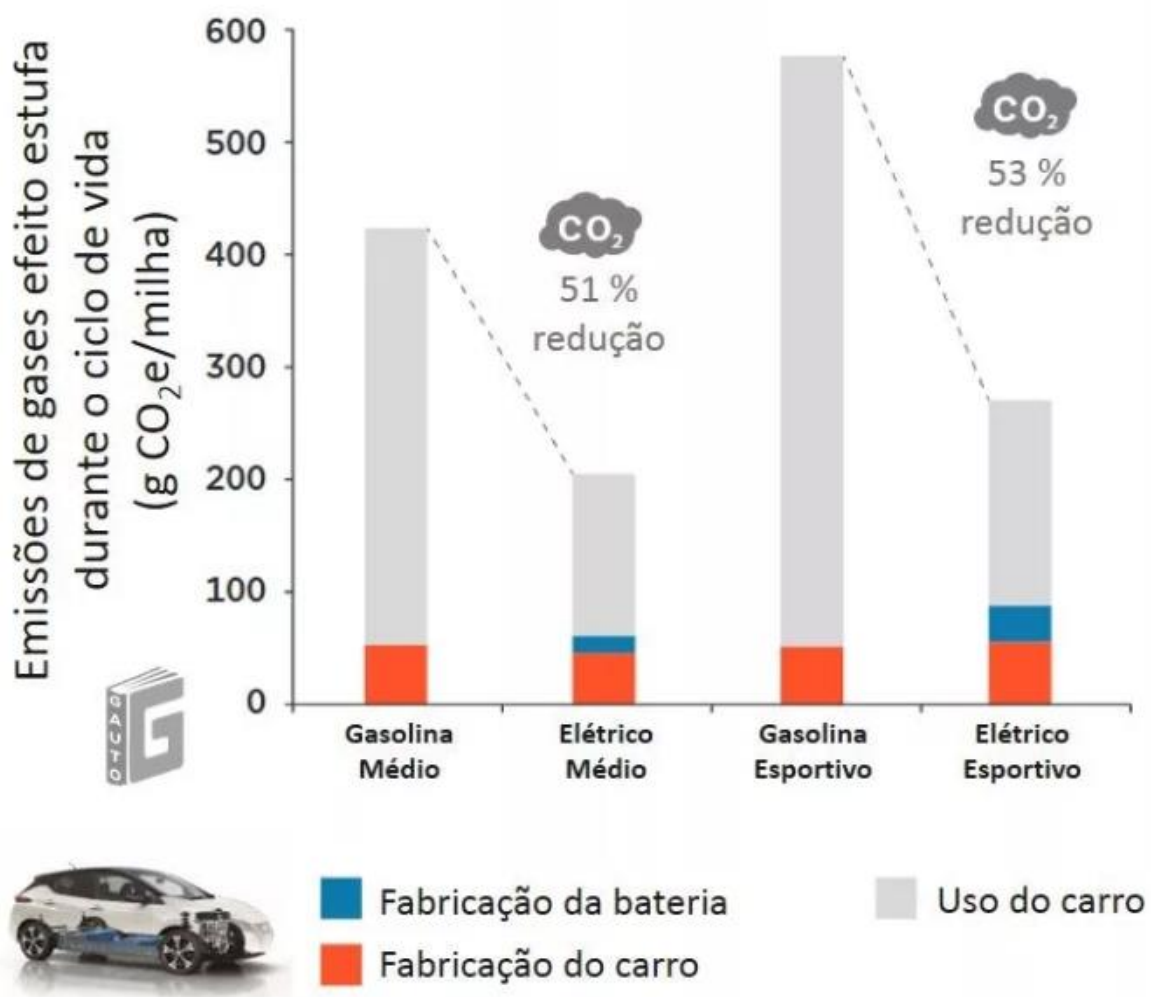

Nota: Ciclo de vida dos veículos médios de 135.000 milhas e dos esportivos de 179.000 milhas. As emissões de gases durante a fabricação dos carros consideram a intensidade média da rede elétrica dos EUA, enquanto a do uso carro considera a intensidade média de onde ele é vendido.

Fonte: < Adaptado de Union Of Concerned Scientists: Cleaner Cras From Cradle to Grave, 2015.>

Acompanhando a tendência mundial, este trabalho tem como objetivo a criação de eletro-postos nos campus da UFSM que irá possibilitar, para usuários de veículos elétricos, uma integração mais prática entre as sedes, além de serem os primeiros eletro-postos de três das quatro cidades em que a UFSM se encontra, introduzindo e incentivando o uso desse tipo de veículo. Com esses novos pontos de recarga as cidades também irão possibilitar a conexão com Porto Alegre, capital e região mais habitada do estado, sendo a origem da maioria dos servidores e discentes da universidade.

De acordo com o IBGE, as quatro cidades sedes da UFSM tem uma população estimada de 430 mil de habitantes, e se considerarmos que esses eletro-postos podem influenciar regiões de até $50 \mathrm{Km}$ de distância, eles irão atender a 7I municípios e uma população estimada de I,I milhão de habitantes. Como os eletropostos da UFSM 
terão o caráter de ser público e gratuito, não só a população acadêmica da universidade irá se beneficiar, e sim a população local em geral [2I].

O projeto terá grande impacto para a UFSM, tanto na parte ambiental como financeira, visto que servidores da instituição muitas vezes têm de se locomover de um campus para o outro para diversas atividades. Entre essas atividades estão o transporte de materiais e equipamentos da entidade que facilmente poderiam ser realizados com veículos elétricos, trazendo economia para a universidade. Com a construção desses eletropostos, além dos veículos adquiridos pela UFSM, a comunidade também terá um incentivo para a aquisição de veículos elétricos, pois terão pontos de recarga rápida nas rotas entre os campus.

Sendo uma região com a economia baseada majoritariamente no agronegócio, outro fator importante da criação dos eletropostos será a introdução da tecnologia de veículos elétricos nessas regiões, podendo impulsionar a adesão de moradores e fazendeiros à essa tecnologia, que já está se inserindo no mercado agrícola, com tratores e outras máquinas.

Portanto, o presente artigo se justifica, pois a Universidade Federal de Santa Maria e seus campi estão em um ponto estratégico no estado, além disso, a instituição já possui um processo de implantação da Agenda 2030, visando ser referenciada tanto nacional quanto internacionalmente, além de já possuir um veículo elétrico e um eletroposto rápido, em conjunto com o Centro de Excelência em Energia e Sistemas de Potência (CEESP) da instituição.

\section{ESTADO DA ARTE}

Saavedra, Álvarez e Sánchez, 2019, indicam que na Colômbia o setor de transportes é o maior consumidor de energia, com 38\% da demanda nacional de energia. Por outro lado, a Colômbia, apesar de ser um dos países com maior riqueza hídrica do mundo, obtém a maior parte de sua energia a partir de combustíveis fósseis $[15]$.

Com base nisso, pode-se afirmar que o maior gerador de gases de efeito estufa do país é o setor de transportes, o que o torna centro das atenções para o desenvolvimento e implementação de alternativas sustentáveis. Diante desse problema e dos avanços alcançados em outras regiões do mundo nessa área, Saavedra 
et al. propor como solução a promoção da utilização de veículos elétricos, que apresentam uma eficiência energética superior aos de combustão interna [15].

A conjuntura mundial reflete uma tendência clara de inclusão dos veículos elétricos nas alternativas de transporte, sendo os Estados Unidos, a Ásia e a Europa os principais responsáveis por esta mudança. Por sua vez, na Colômbia foram realizados alguns projetos para instalar postos de recarga de veículos elétricos e incluir esses tipos de veículos no sistema de transporte público de algumas cidades, como Medellín e Bogotá.

Com base no contexto atual da Colômbia em relação aos veículos elétricos, Saavedra et al. Seu objetivo é o projeto e desenvolvimento de estações de carregamento elétrico sustentáveis no país.

Como um primeiro passo no desenvolvimento do projeto, diferentes alternativas para estações de carregamento são propostas:

- Recarga na rua: como principais pontos deste tipo de recarga, destaca-se que é utilizado principalmente para viagens curtas, a alimentação é da rede de iluminação, o custo dos conectores é superior a US $\$$ Ioo, não é padronizado e o tempo de recarga é lento;

- Estação wireless: seu custo estimado ultrapassa US\$25.00o, não é padronizada, sua eficiência fica entre 50\% e 80\% e o tempo de recarga é lento;

- Estação doméstica: a localização representa uma limitação, sua custódia é superior a US $\$$ I.ooo, não é padronizada e o tempo de recarga é lento. Este é um modelo recomendado para queimar o rosto ao sair de casa;

- Estação sustentável: o custo estimado é entre US\$80.00o e US\$ 10o.ooo, e possui opção de trabalho offgrid e ongrid. Por ser de fonte renovável de energia, é a estação com menor custo operacional. Por outro lado, possui o menor tempo estimado de recarga em comparação com as 3 opções anteriores.

Saavedra et al, pegaram quatro critérios para determinar a melhor alternativa para seu projeto: investimento inicial, custos de instalação, operação e manutenção e tempo de recarga. Com base nos critérios acima, a estação de carregamento sustentável foi selecionada [15]. 
O projeto proposto por Saavedra consiste em duas fontes de energia: um sistema fotovoltaico e a opção de interligação à rede elétrica convencional. A energia elétrica DC fornecida pelos painéis solares é armazenada em baterias de lítio, que têm uma taxa de carga / descarga regulada por um controlador de carga. Já a rede elétrica convencional é incorporada ao sistema por meio de um conversor CA-CC (incluindo seu sistema de proteção). Por fim, o sistema de controle da estação de carregamento é responsável por carregar os veículos com a energia proveniente do sistema fotovoltaico ou da rede elétrica convencional. A seguir, na imagem i6 está o projeto proposto por Saavedra.

Imagem 16 - Projeto proposto por Saavedra

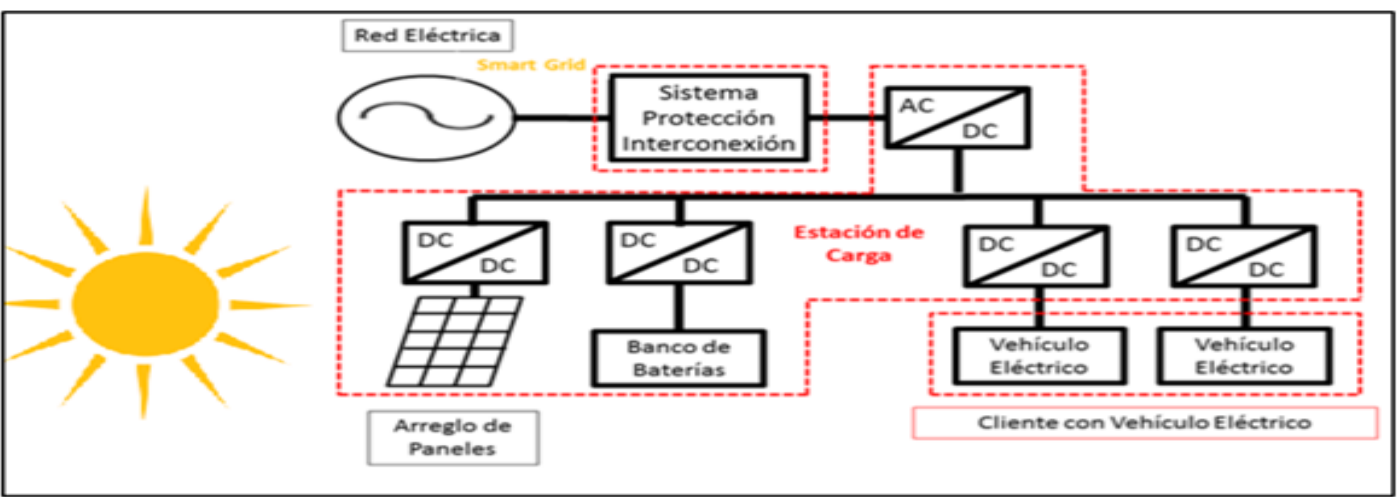

Fonte: Saavedra Muñoz, Matilde.; Alvarez Villa, Diego.; Alejandro Sánchez Wilches,Elkin Asdrúbal. Diseño, construccion y puesta en marcha de eco-electrolineras.

Por outro lado, a Universidade Federal de Santa Maria participou como executora de um projeto de pesquisa e desenvolvimento tecnológico, apresentado em 2009 pela Copel Distribuição SA, denominado "Interface de Inovação Multiagente envolvendo a indústria automobilística, os sistemas de energia e infraestruturas de mobilidade elétrica para eletro vias inteligentes”. O objetivo geral do projeto é desenvolver "um sistema de gestão inteligente de eletro vias com interoperabilidade entre os distribuidores de energia, usuários, indústria automotiva, fabricantes, operadores de pontos de carregamento e instituições públicas, com vistas à promoção da eletromobilidade".

Entre os produtos entregues pelo projeto estão dois modelos, um para gestão inteligente e outro empresarial para aplicação em eletrovias, e estações de recarga com módulos fotovoltaicos e de armazenamento. O sistema também inclui 
informações coletadas por meio de aprendizado de máquina e modelos em tempo real. O projeto também propõe a instalação de duas estações de carregamento rápido para veículos leves e pesados.

Em relação aos custos associados ao projeto, estima-se um total de R $\$ 6.147 .649,04$ (seis milhões cento e quarenta e sete mil seiscentos e quarenta e nove reais e quatro centavos). A tabela de custos associados é apresentada a seguir:

Tabela 02 - Custos associados ao projeto

\begin{tabular}{|c|c|c|c|c|c|c|}
\hline Rubrica & $\begin{array}{c}\text { Contrapart } \\
\text { idas Valor } \\
\text { (R\$) }\end{array}$ & $\begin{array}{c}\text { Percentual } \\
(\%)\end{array}$ & $\begin{array}{c}\text { Programa } \\
\text { de P\&D } \\
\text { Valor (R\$) }\end{array}$ & $\begin{array}{c}\text { Percentual } \\
(\%)\end{array}$ & $\begin{array}{c}\text { Total Valor } \\
\mathbf{( R \$ )}\end{array}$ & $\begin{array}{c}\text { Percentual } \\
\mathbf{( \% )}\end{array}$ \\
\hline $\begin{array}{c}\text { Recursos } \\
\text { Humahos }\end{array}$ & $216.331,2$ & 19,6 & $2.437 .438,0$ & 48,3 & $2.653 .769,2$ & 43,2 \\
\hline $\begin{array}{c}\text { Material } \\
\text { Permanent } \\
\text { e }\end{array}$ & $468.900,0$ & 42,5 & $1.617 .000,0$ & 32,1 & $2.085 .900,0$ & 33,9 \\
\hline $\begin{array}{c}\text { Material de } \\
\text { Consumo }\end{array}$ & $1.000,0$ & 0,1 & $21.600,0$ & 0,4 & $22.600,0$ & 0,4 \\
\hline $\begin{array}{c}\text { Serviços de } \\
\text { Terceiros }\end{array}$ & $162.100,0$ & 14,7 & $425.000,0$ & 8,4 & $587.100,0$ & 9,5 \\
\hline $\begin{array}{c}\text { Viagens e } \\
\text { Diárias }\end{array}$ & $20.000,0$ & 1,8 & $259.420,0$ & 5,1 & $279.420,0$ & 4,5 \\
\hline $\begin{array}{c}\text { Outros } \\
\text { Gastos }\end{array}$ & $235.429,9$ & 21,3 & $283.429,9$ & 5,6 & $518.859,8$ & 8,4 \\
\hline Total & $\mathbf{1 . 1 0 3 . 7 6 1 , 1}$ & $\mathbf{1 0 0 , 0}$ & $\mathbf{5 . 0 4 3 . 8 8 7 , 9}$ & $\mathbf{1 0 0 , 0}$ & $\mathbf{6 . 1 4 7 . 6 4 9 , 0}$ & $\mathbf{1 0 0 , 0}$ \\
\hline
\end{tabular}

Fonte: Saavedra Muñoz, Matilde.; Alvarez Villa, Diego.; Alejandro Sánchez Wilches,Elkin Asdrúbal. Diseño, construccion y puesta en marcha de eco-electrolineras.

Por fim, Fabre (2017) levanta em seu projeto a necessidade de haver postos de recarga semi-rápida para veículos elétricos em diferentes áreas da cidade de Guayaquil, a fim de incentivar o uso deste tipo de veículo e, consequentemente, a redução de emissões de gases de efeito estufa na cidade. [19]

Fabre (2017) propõe a instalação de estações com dois pontos de recarga cada, que terão capacidade para movimentar dois veículos ao mesmo tempo. Esses veículos, com bateria de $27 \mathrm{~kW}$, poderão completar sua carga em aproximadamente uma hora e trinta minutos. Levando em conta também os veículos que já se encontram no Equador, propõe-se a utilização dos seguintes tipos de conectores: Mennekes e Yazaki. [19] 
O modelo de estação de recarga escolhido no projeto foi o BLAUBOX GROUND $22 \mathrm{~kW}$, cujas características são apresentadas a seguir:

- Potência: $22 \mathrm{~kW}$;

- Portas de carregamento: 2;

- Conector: Mennekes / Yazaki;

- Garantia: 2 anos;

- Sistema de pagamento integrado opcional;

- Projetado antivandalismo. Estrutura de aço, com portas fechadas por eletroímã;

- Projetado para ser exposto ao ar livre;

- LED de iluminação de status de carregamento.

Imagem 17 - Eletroposto do projeto proposto por Saavedra

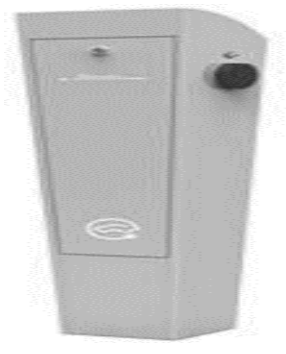

Fonte: Saavedra Muñoz, Matilde.; Alvarez Villa, Diego.; Alejandro Sánchez Wilches,Elkin Asdrúbal. Diseño, construccion y puesta en marcha de eco-electrolineras.

Em relação aos custos associados ao projeto, Fabre (2017) propõe o seguinte investimento inicial:

Tabela 03 - Custos associados ao investimento inicial do projeto

\begin{tabular}{|c|c|c|}
\hline Rubrica & Custo (USD \$) & Percentagem (\%) \\
\hline $\begin{array}{c}\text { EQUIPAMENTO DA ESTAÇÃO } \\
\text { DE CARGA }\end{array}$ & $8.043,50$ & 66,72 \\
\hline MÓVEIS DE ESCRITÓRIO & $1.050,00$ & $\mathbf{8 , 7 1}$ \\
\hline EQUIPE DA OFICINA & $1.570,00$ & 13,02 \\
\hline INFRAESTRUTURA & 997,40 & $\mathbf{8 , 2 7}$ \\
\hline $\begin{array}{c}\text { EQUIPAMENTOS E FONTES } \\
\text { DE PAGAMENTO }\end{array}$ & 395,00 & $\mathbf{1 0 0}$ \\
\hline TOTAL & $\mathbf{1 2 . 0 5 5 , 9 0}$ & \\
\hline
\end{tabular}

Fonte: Saavedra Muñoz, Matilde.; Alvarez Villa, Diego.; Alejandro Sánchez Wilches,Elkin Asdrúbal. Diseño, construccion y puesta en marcha de eco-electrolineras. 


\subsection{O carro adquirido pela UFSM}

Os modelos Leaf padrão vêm com um motor elétrico de 149 cavalos que aciona as rodas dianteiras e possui uma bateria de 40,o $\mathrm{kWh}$ fornece o a energia para o acionamento do motor. O carro faz $\mathrm{Ioo} \mathrm{Km} / \mathrm{h}$ em 7,4 segundos. Possui o recurso ePedal que permite que o motorista alterne entre os modos de frenagem regenerativa, ou seja, quando o condutor tirar o pé do acelerador o sistema usa essa energia para recarregar a bateria. A Tabela 04 mostra as especificações técnicas do veículo e a imagem I9 mostra o veículo propriamente dito.

Tabela 04 - Especificações Técnicas Nissan Leaf

\begin{tabular}{|c|c|}
\hline & $\begin{array}{c}\text { LEAF } \\
\text { [40KW/H] }\end{array}$ \\
\hline \multicolumn{2}{|l|}{ Motor } \\
\hline Tipo & Elétrico $(110 \mathrm{kw})$ \\
\hline Potência & $149 \mathrm{cv} @ 9.795 \mathrm{rpm}$ \\
\hline Torque & $32,6 \mathrm{kgfm} @ 3.283 \mathrm{rpm}$ \\
\hline \multicolumn{2}{|l|}{ Eléctrico } \\
\hline Tipo de bateria & 40 kWh Bateria ion-lítio laminada \\
\hline \multicolumn{2}{|l|}{ Tração } \\
\hline Eixo & $2 W D$ \\
\hline \multicolumn{2}{|l|}{ Suspensão } \\
\hline Dianteira & Independente tipo McPherson com Barra estabilizadora \\
\hline Traseira & Eixo de torção com Barra Estabilizadora \\
\hline \multicolumn{2}{|l|}{ Freios } \\
\hline Dianteiros e Traseiros & Disco dianteiras e traseiros ventilados \\
\hline \multicolumn{2}{|l|}{ Direçã̃o } \\
\hline Tipo & Elétrica com assistência variável \\
\hline \multicolumn{2}{|l|}{ Dimensões exteriores } \\
\hline Comprimento & $4.480 \mathrm{~mm}$ \\
\hline Largura & $1.790 \mathrm{~mm}$ \\
\hline Allura & $1.565 \mathrm{~mm}$ \\
\hline Âltura livre do solo & $155 \mathrm{~mm}$ \\
\hline Distância entre-eixos & $2.700 \mathrm{~mm}$ \\
\hline \multicolumn{2}{|l|}{ Rodas } \\
\hline Rodas & Liga leve 17" \\
\hline Pneus & $215+50 \mathrm{R} 17^{n}$ \\
\hline \multicolumn{2}{|l|}{ Capacidade } \\
\hline Capacidade de Passageiros & 5 \\
\hline Emissão de CD2 & 0 \\
\hline Porta-malas & $435 \mathrm{~L}$ \\
\hline
\end{tabular}

Fonte: 〈https://www.icarros.com.br/nissan/leaf/ficha-tecnica〉 
Imagem 19 - Especificações Técnicas Nissan Leaf

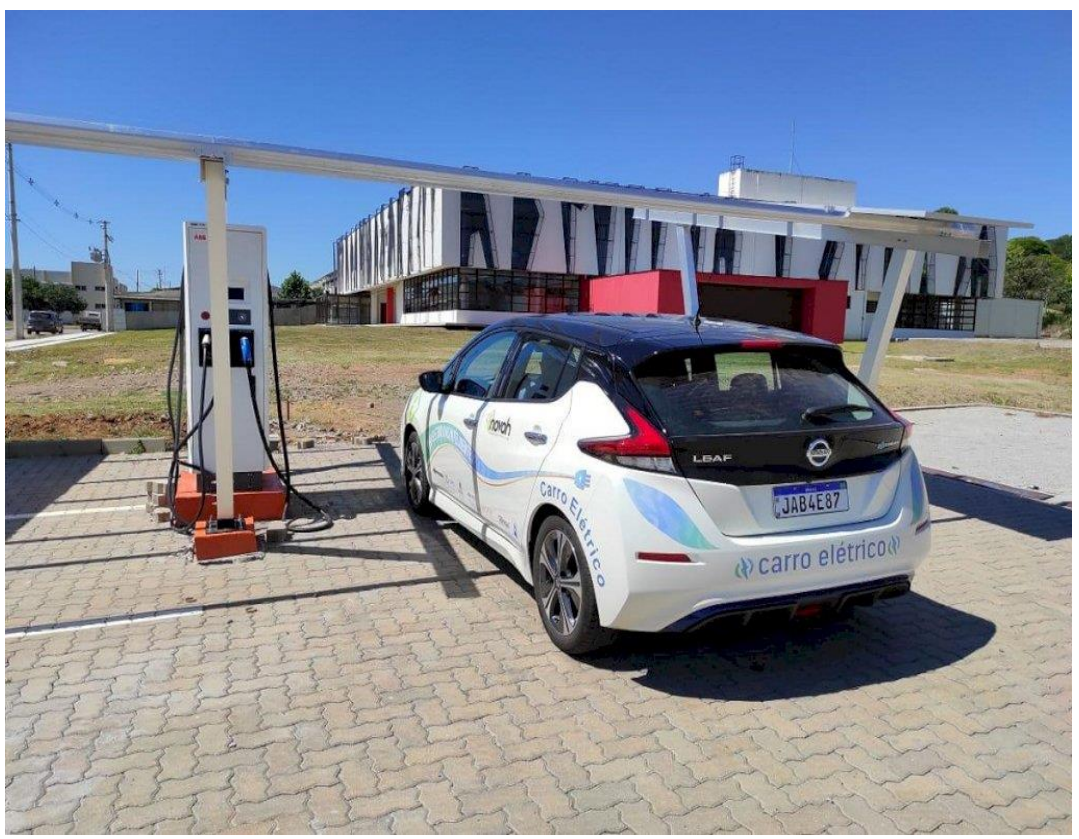

Fonte: <https://diariosm.com.br/colunistas/colunistas-do-site/deni-zolin/posto-para-recarregarcarros-el\% $\mathrm{C}_{3 \%}$ A9tricos-na-ufsm-deve-ficar-pronto-em-janeiro-I.2289002>

\section{DESENVOLVIMENTO DA PROPOSTA}

O presente tópico do trabalho busca discorrer sobre o desenvolvimento da proposta do projeto, analisando as cidades sedes, os trajetos, os veículos, a influência e o impacto social.

\section{I Cidades Sede}

A Universidade Federal de Santa Maria, tem seus cursos descentralizados, possuindo hoje 4 campus dentro do Rio Grande do Sul. O maior deles, localizado em Santa Maria - RS, abrange grande parte dos cursos e setores administrativos da universidade, dessa forma, semanalmente são realizadas diversas viagens entre campus, a maioria delas, saindo de Santa Maria para algum campus ou saindo de algum campus para Santa Maria.

Utilizando os dados de população do IBGE e as distâncias entre as cidades gaúchas até uma das sedes por meio da biblioteca GeoPy, foi levantado que 7I cidades estão a até $50 \mathrm{~km}$ de distância de uma dessas sedes, com cerca de I,I milhão de habitantes que poderão ser beneficiados com o desenvolvimento de eletro-mobilidade na região, como mostrado pelos gráficos e tabela abaixo. 
Tabela 05 - Distância x Cidade x Crescimento Populacional

\begin{tabular}{|c|c|c|c|}
\hline \multicolumn{1}{|c}{ Distância (km) } & Cidades & População 2010 & População 2020 \\
\hline 0 & 4 & 415453 & 429477 \\
\hline 5 & 4 & 415453 & 429477 \\
\hline 10 & 7 & 426326 & 440099 \\
\hline 15 & 9 & 442239 & 456348 \\
\hline 20 & 13 & 457072 & 471494 \\
\hline 25 & 21 & 497301 & 509488 \\
\hline 30 & 29 & 521023 & 533669 \\
\hline 35 & 38 & 567070 & 576864 \\
\hline 40 & 49 & 657805 & 669704 \\
\hline 45 & 62 & 760562 & 772775 \\
\hline 50 & 71 & 1089851 & 1133001 \\
\hline
\end{tabular}

Fonte: Os Autores

O gráfico abaixo demonstra o número de cidades que estão a até $50 k m$ de distância de uma das sedes da UFSM.

Gráfico 04 - Número de Municípios X Distância

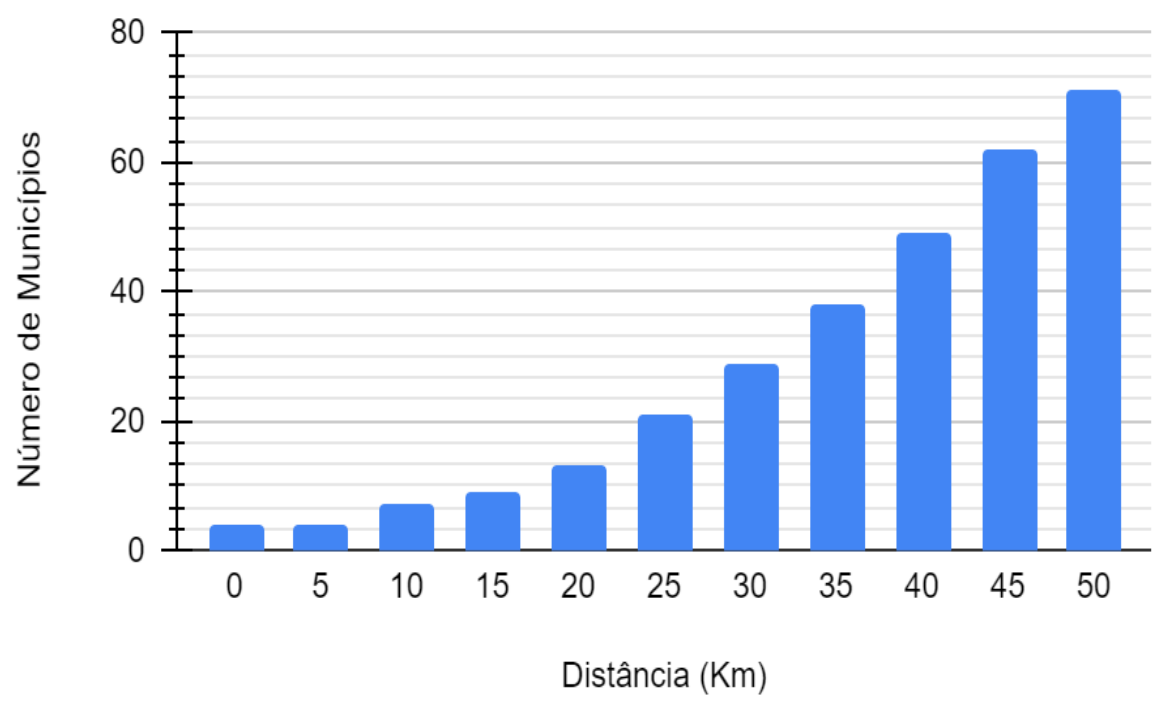

Fonte: Os Autores

Levando em conta o número de habitantes de cada umas dessas cidades, foi possível elaborar um gráfico que demonstra o número de pessoas que serão impactadas com a construção dos eletropostos. O gráfico os demonstra esses resultados. 


\section{Gráfico os - População X Distância}

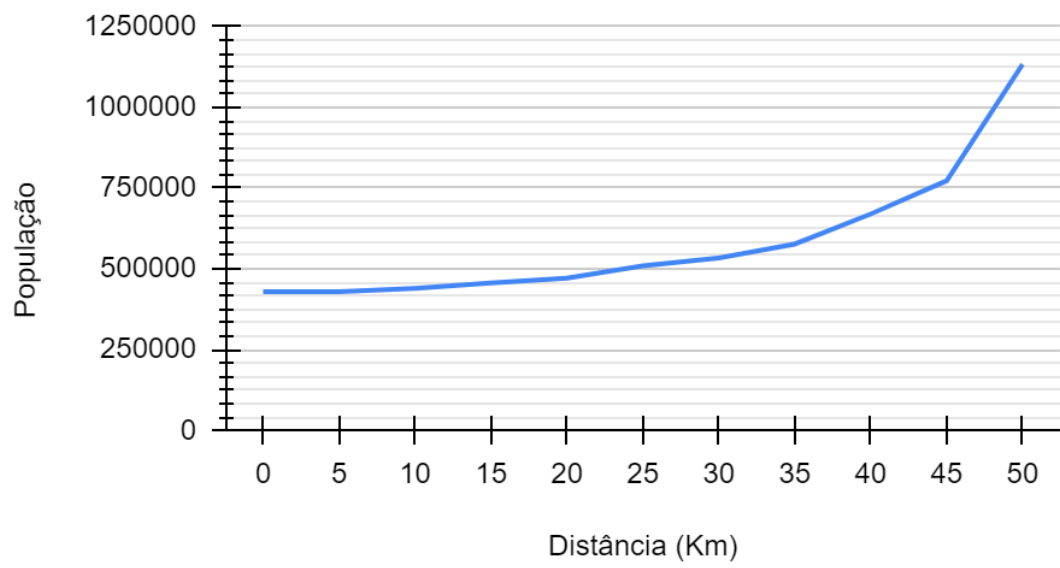

Fonte: Os Autores

De acordo com o PlugShare visualizado na imagem 20 a seguir, das cidades sedes, apenas Santa Maria possui eletro-postos públicos, sendo eles o "Parceria Solar" na avenida João Luiz Pozzobon 736, com plugs “Type 2" e "Wall” que está para inauguração em breve, "Neo Autoposto" na avenida Nossa Sra. das Dores 418, com plug "Type 2" e "Universidade Federal de Santa Maria (CEESP)" na avenida Roraima Iooo, com plugs "CHAdeMO", “Type 2" e "CCS/SAE”, sendo esse o único de recarga rápida. [4]

Imagem 20 - Eletroposto por cidade

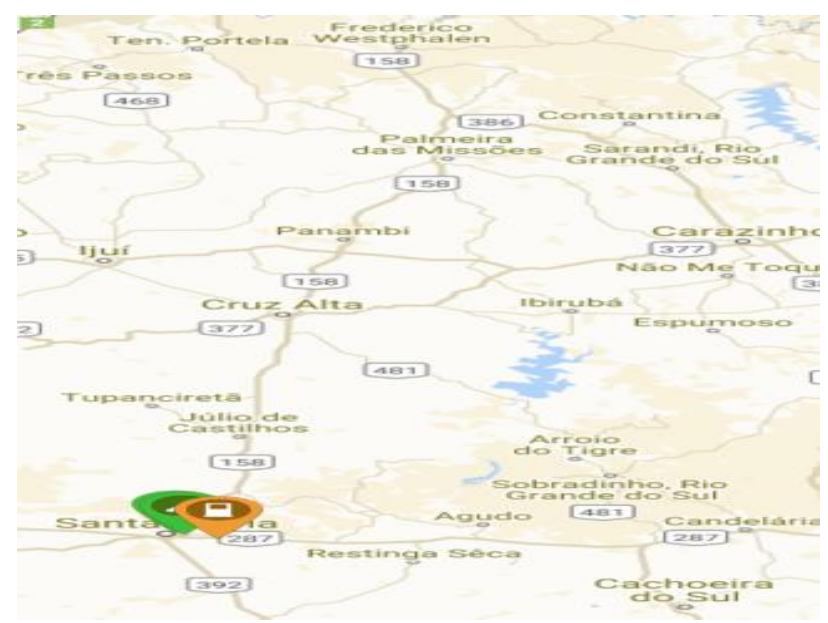

Fonte: $\langle$ https://www.plugshare.com/ $>$ [4]

As viagens realizadas nos veículos oficiais da universidade têm diversos objetivos como transportar servidores para realizar reuniões, manutenções, serviços 
gerais e até mesmo realizar o transporte de amostras para serem analisadas em Santa Maria.

Portanto, para a escolha do veículo elétrico adequado questões como autonomia, número de passageiros e volume de porta-malas foram levados em consideração. A Tabela 05 traz a relação de distâncias entre as cidades onde existem campus da UFSM, além de contar com a cidade de Porto Alegre, capital do estado, para onde também são realizadas viagens.

Tabela o5 - Distâncias entre as cidades

\begin{tabular}{|c|c|c|c|c|c|}
\hline Distância (km) & $\begin{array}{l}\text { Santa } \\
\text { Maria }\end{array}$ & $\begin{array}{c}\text { Cachoeira do } \\
\text { Sul }\end{array}$ & $\begin{array}{c}\text { Palmeira das } \\
\text { Missões }\end{array}$ & $\begin{array}{c}\text { Frederico } \\
\text { Westphalen }\end{array}$ & $\begin{array}{l}\text { Porto } \\
\text { Alegre }\end{array}$ \\
\hline Santa Maria & - & 114 & 228 & 290 & 280 \\
\hline $\begin{array}{c}\text { Cachoeira do } \\
\text { Sul }\end{array}$ & 114 & - & 318 & 383 & 198 \\
\hline $\begin{array}{c}\text { Palmeira das } \\
\text { Missōes }\end{array}$ & 228 & 318 & - & 69 & 374 \\
\hline $\begin{array}{c}\text { Frederico } \\
\text { Westphalen }\end{array}$ & 290 & 383 & 69 & - & 423 \\
\hline Porto Alegre & 280 & 198 & 374 & 423 & - \\
\hline
\end{tabular}

Fonte: Os Autores

Como a maioria das viagens tem como destino ou partida Santa Maria, as análises principais de distância são a partir dessa cidade, como visualizadas no gráfico a seguir.

Gráfico o6 - Distâncias até Santa Maria

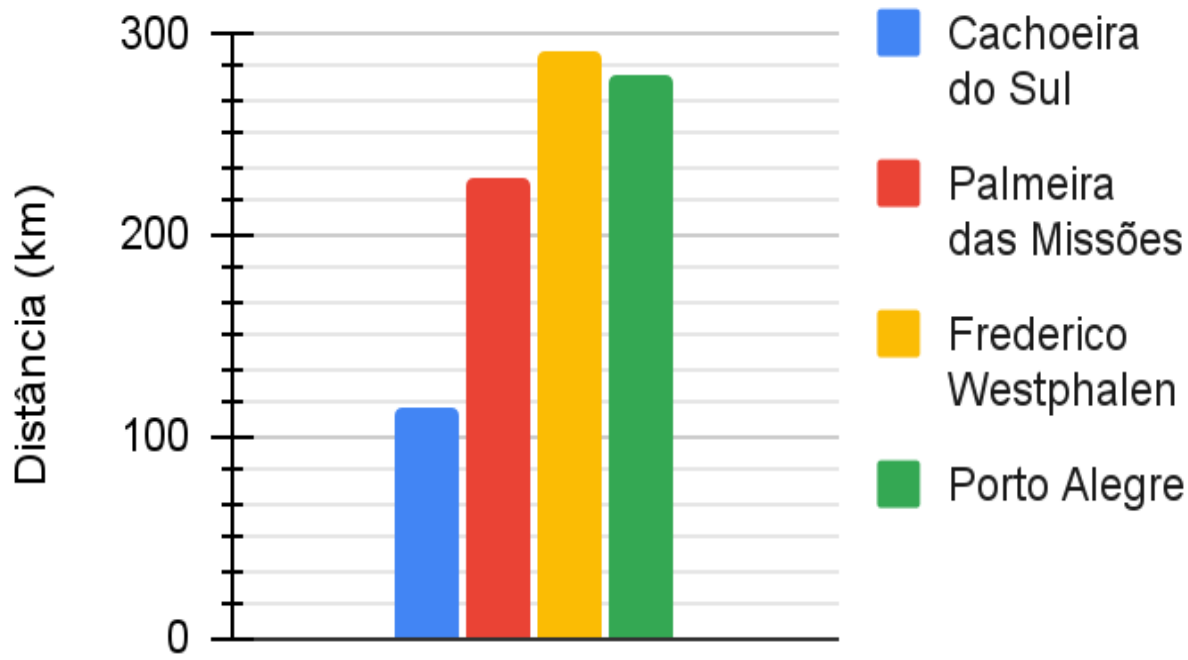


Fonte: Os Autores

Entre Santa Maria e Cachoeira do Sul é realizado um trajeto de $114 \mathrm{~km}$, com estimativa de viagem de $\mathrm{th}$ e $30 \mathrm{~min}$, sendo as principais vias percorridas a $\mathrm{BR}_{287} / \mathrm{RS}_{149}$ e BRI53, que é toda asfaltada, como mostrado na imagem.

Imagem 2I - Percurso entre Santa Maria e Cachoeira do Sul

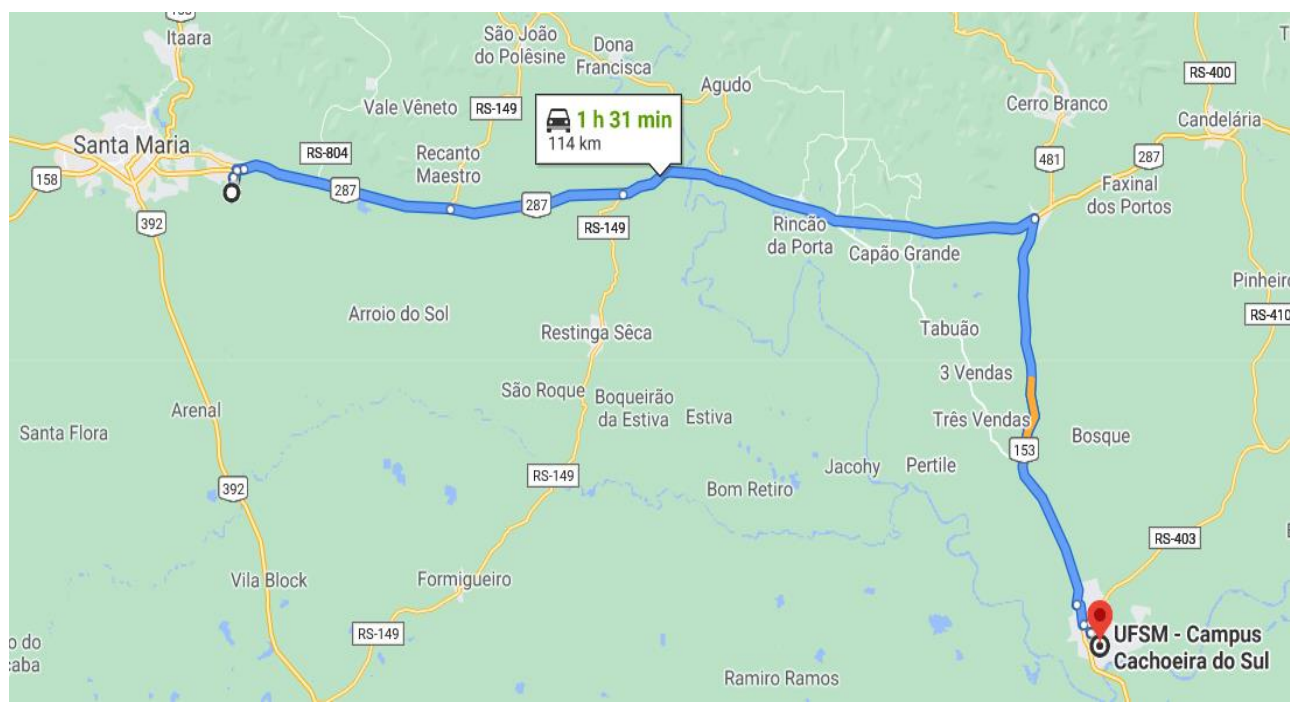

Fonte: Os Autores

De Santa Maria para Frederico Westphalen é percorrido uma distância de $225 \mathrm{~km}$ e uma estimativa de viagem de $3 \mathrm{~h}$ até Palmeira das Missões e mais $70 \mathrm{~km}$ com estimativa de Ih até chegar em Frederico Westphalen. A principal via desse trajeto é a BRI58, sendo mostrada nas imagens.

Imagem 22 - Percurso entre Santa Maria/Palmeira das Missões/Frederico Westphalen

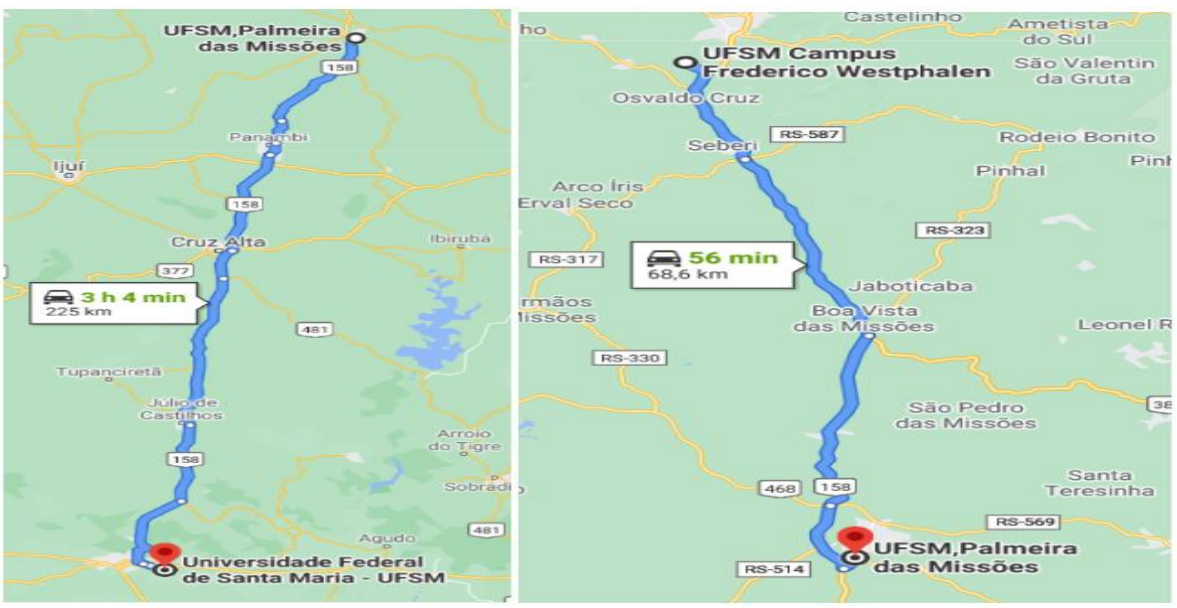

Fonte: Os Autores 
Com a definição dos eletropostos, as rodovias BRI53, BRI57 e $\mathrm{BR}_{287}$ serão as mais beneficiadas, tendo em vista que os eletropostos ficam nas suas proximidades.

\subsection{Análise dos Trajetos}

Foi realizado um comparativo entre os veículos elétricos disponíveis no Brasil, comparando suas autonomias (retiradas da ficha técnica dos veículos) até a distância de $350 \mathrm{~km}$ para verificar quais carros teriam autonomia suficiente para percorrer esta distância.

Tabela o6 - Comparativo entre Veículos Elétricos

\begin{tabular}{|c|c|c|c|c|}
\hline \multirow{2}{*}{$\begin{array}{c}\text { Veiculo } \\
\text { Preço }\end{array}$} & \multicolumn{2}{c|}{ Potência/Torque } & $\begin{array}{c}\text { Velocidade } \\
\text { Máxima }\end{array}$ & $\begin{array}{c}\text { Autonomia } \\
\text { (km) }\end{array}$ \\
\hline JAC iEV20 & $\mathrm{R} \$ 159.900$ & $68 \mathrm{cv} / 21,9 \mathrm{kgfm}$ & $113 \mathrm{~km} / \mathrm{h}$ & 400 \\
\hline Renault Zoe & $\mathrm{R} \$ 203.678$ & $88 \mathrm{cv} / 22 \mathrm{kgfm}$ & $135 \mathrm{~km} / \mathrm{h}$ & 300 \\
\hline Chery Arrizo $5 \mathrm{e}$ & $\mathrm{R} \$ 159.990$ & $122 \mathrm{cv} / 28,1 \mathrm{kgfm}$ & $152 \mathrm{~km} / \mathrm{h}$ & 322 \\
\hline JAC iEV40 & $\mathrm{R} \$ 225.900$ & $115 \mathrm{cv} / 30,6 \mathrm{kgfm}$ & $130 \mathrm{~km} / \mathrm{h}$ & 300 \\
\hline Nissan Leaf & $\mathrm{R} \$ 259.900$ & $149 \mathrm{cv} / 33 \mathrm{kgfm}$ & $143 \mathrm{~km} / \mathrm{h}$ & 389 \\
\hline BMW i3 & $\mathrm{R} \$ 279.950$ & $170 \mathrm{cv} / 25 \mathrm{kgfm}$ & $150 \mathrm{~km} / \mathrm{h}$ & 335 \\
\hline Chevrolet Bolt & $\mathrm{R} \$ 274.000$ & $203 \mathrm{cv} / 36 \mathrm{kgfm}$ & $148 \mathrm{~km} / \mathrm{h}$ & 416 \\
\hline Jaguar I-Pace & $\mathrm{R} \$ 452.200^{*}$ & $400 \mathrm{cv} / 696 \mathrm{kgfm}$ & $200 \mathrm{~km} / \mathrm{h}$ & 470 \\
\hline Audi e-tron & $\mathrm{R} \$ 529.990$ & $408 \mathrm{cv} / 66.7 \mathrm{kgfm}$ & $200 \mathrm{~km} / \mathrm{h}$ & 436 \\
\hline JAC iEV60 & $\mathrm{R} \$ 259.900$ & $150 \mathrm{cv} / 33.65 \mathrm{kgfm}$ & $130 \mathrm{~km} / \mathrm{h}$ & 380 \\
\hline JAC iEV330P & $\mathrm{R} \$ 299.900$ & $150 \mathrm{cv} / 33.65 \mathrm{kgfm}$ & $97 \mathrm{~km} / \mathrm{h}$ & 320 \\
\hline
\end{tabular}

Fonte: Os Autores

Dessa forma, é possível visualizar que a maioria dos veículos elétricos disponíveis no Brasil atendem a necessidade do projeto.

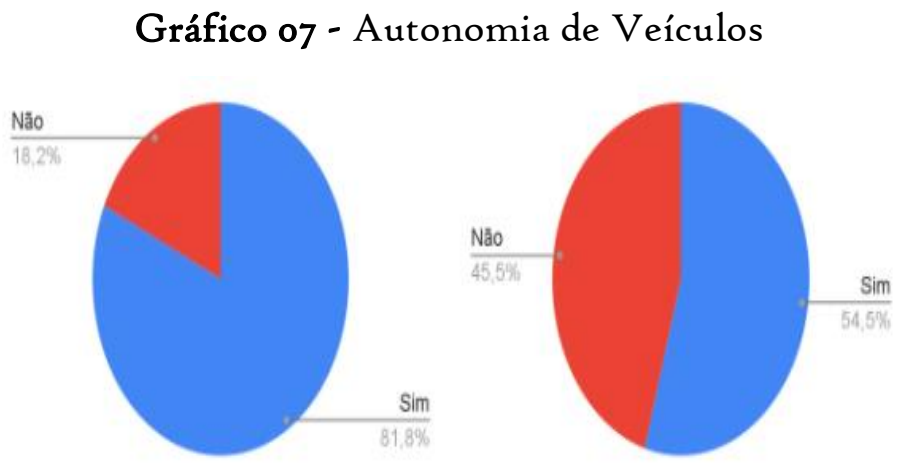

Fonte: Os Autores

Levando em conta a autonomia, número de passageiros que o veículo consegue transportar e volume de porta-mala, o Nissan Leaf foi considerado o modelo mais adequado para as necessidades da UFSM. 
Para recarga dos veículos, o eletroposto contará com carregador rápido modelo ABB de 5okW (Terra 54 DC Fast Charger). Levou-se em consideração a experiência prévia nesta utilização deste modelo e atender a necessidade do projeto. Este carregador conecta-se a ABB's network operations center possibilitando suporte rápido e remoto, diminuindo os custos de manutenção em visitas presenciais. Além disso, conta com IT resources conectado a ABB Ability cloud que monitora e armazena os dados de recarga.

Imagem 23 - Posto de Recarga Rápida

INFOGRAPHIC | Terra 54 DC Fast Charger

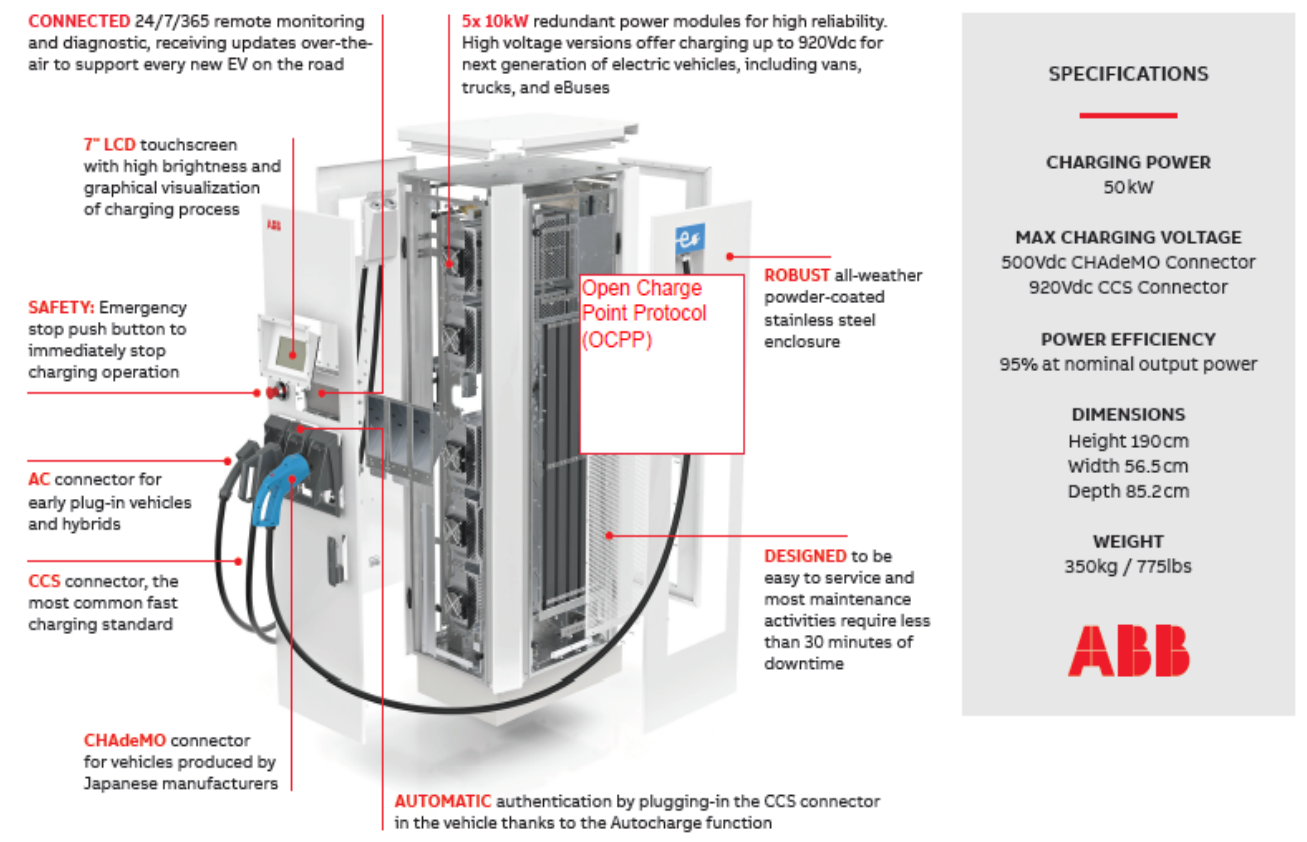

Fonte: $\langle$ https://new.abb.com/ev-charging/products/car-charging/dc-fast-chargers> [24]

\subsection{Análise de Influência}

Adotando-se um raio de influência de $125 \mathrm{~km}$ em cada eletroposto, pois dos veículos elétricos analisados, todos possuem autonomia superior à $250 \mathrm{~km}$, dessa maneira seria possível do veículo ir do eletroposto, percorrer $125 \mathrm{~km}$ de distância sem carregar e retornar. É possível visualizar no mapa que os novos eletropostos nas sedes da UFSM irão abranger uma grande área do estado que não possuía esse tipo de tecnologia, criando uma nova alternativa às pessoas que necessitam realizar estes trajetos. 
Imagem 24 - Área de Abrangência do Projeto

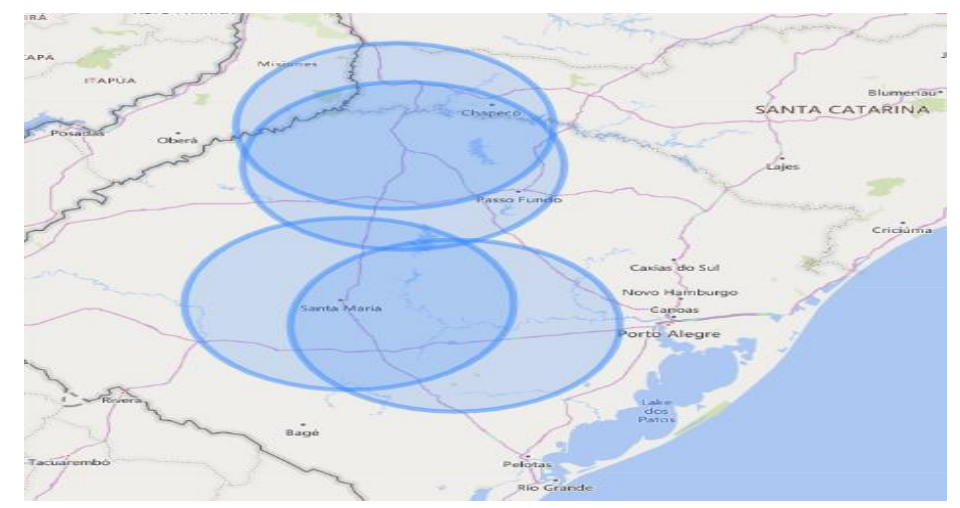

Fonte: Os Autores

\subsection{Impacto Social}

Em contato realizado por e-mail, de acordo com o núcleo de transporte da UFSM, foram realizadas 513 viagens entre Santa Maria e as outras sedes. Considerando as distâncias entre os campus, que já foram demonstradas anteriormente, e considerando o trajeto da viagem de ida e volta, estima-se que por ano, a distância total percorrida nestas viagens é de aproximadamente 164 mil quilômetros.

O gráfico abaixo expõe o número de viagens realizadas mensalmente entre Santa Maria para as outras sedes durante o ano de 2019.

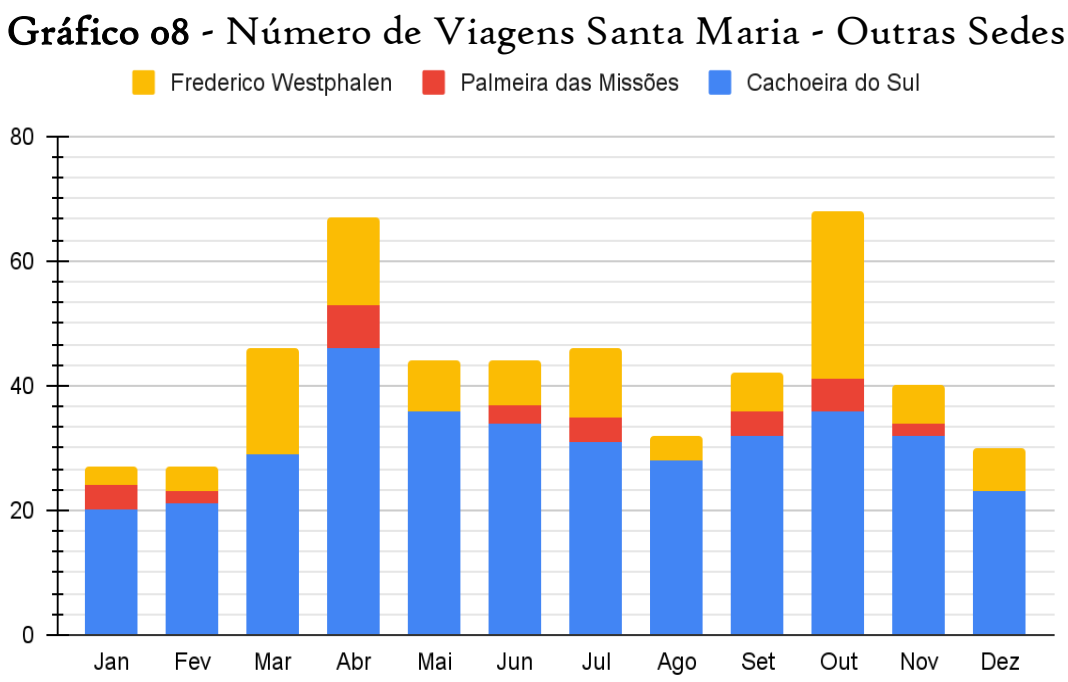

Fonte: Os Autores

De acordo com Agência Nacional do Petróleo, o custo médio de gasolina no estado do Rio Grande do Sul, no mês de abril de 2021 era de R 5,50 [25], dessa forma, 
assumindo que um carro tem uma autonomia média de $16 \mathrm{~km} / \mathrm{l}$, foram gastos pela UFSM em 2019 aproximadamente $\mathrm{R}$ \$56.430,00 com combustível durante um ano.

Considerando o caso do carro escolhido, o Nissan LEAF, que tem uma autonomia considerada de $250 \mathrm{~km}$, com uma bateria de $40 \mathrm{kWh}$, a um custo de energia médio, de acordo com a RGE, no estado do Rio Grande do Sul de $\mathrm{R}_{\$ 0,56}$ o custo total estimado com energia elétrica para suprir as 513 viagens seria de $\mathrm{R} \$ \mathrm{I} 4 \cdot 708,74$.

Em 2016, um litro de combustível gerou 2,12 $\mathrm{kg}$ de $\mathrm{CO}_{2}$, portanto hoje, admitindo-se que a UFSM utilize I026o litros de gasolina, a uma geração anual de $21751 \mathrm{~kg}$ de $\mathrm{CO}_{2}$, que gera uma pegada de carbono que contribui para o aumento do efeito estufa e a degradação do meio ambiente, pontos que vão contra os princípios da universidade e das ODS. Já o carro elétrico não produz $\mathrm{CO}_{2}$ durante o seu funcionamento.

A tabela a seguir demonstra a estipulação do deslocamento anual de veículos de Santa Maria até as outras sedes da UFSM, bem como o gasto caso os veículos utilizados sejam a combustão ou elétricos e a quantidade de gás carbônico que é gerada ou deixaria de ser gerada para cada um dos casos. Para estimativas de custos foram levadas em consideração somente valores ao gasto com combustível, gasolina e eletricidade, sem considerar gastos com manutenção e outros serviços envolvidos

Tabela 07 - Deslocamento Anual de Veículos entre Santa Maria e Outras Sedes

\begin{tabular}{|c|c|c|c|c|}
\hline Santa Maria & Cachoeira do Sul & $\begin{array}{l}\text { Palmeira das } \\
\text { Missões }\end{array}$ & $\begin{array}{c}\text { Frederico } \\
\text { Westphalen }\end{array}$ & \\
\hline Distância (km) & 114 & 228 & 290 & Total Anual \\
\hline Número de Cursos & 5 & 10 & 10 & \\
\hline Número de Viagens & 368 & 31 & 114 & 513 \\
\hline Distância Total (km) & 83904 & 14136 & 66120 & 164160 \\
\hline Litros Consumidos & 5244,00 & 883,50 & 4132,50 & 10260,00 \\
\hline Custo Combustivel & $\mathrm{R} \$ 28.842,00$ & $\mathrm{R} \$ 4.859,25$ & $\mathrm{R} \$ 22.728,75$ & $R \$ 56.430,00$ \\
\hline KWh Consumidos & 13424,64 & 2261,76 & 10579,2 & 26265,6 \\
\hline Custo kWh & $\mathrm{R} \$ 7.517,80$ & $\mathrm{R} \$ 1.266,59$ & $\mathrm{R} \$ 5.924,35$ & $\mathrm{R} \$ 14.708,74$ \\
\hline C02 Gerado & 11117,28 & 1873,02 & 8760,9 & 21751,2 \\
\hline
\end{tabular}

Fonte: Núcleo de Transporte da UFSM [26] 
Projetando os gastos anuais com gasolina, e os gastos previstos com eletricidade para o carregamento das baterias dos veículos elétricos, o gráfico abaixo demonstra a vantagem econômica da utilização dos veículos elétricos. É possível verificar que quanto maior a distância percorrida, mais perceptível é a vantagem do carro elétrico.

Gráfico 09 - Custo Gasolina X Custo Energia

Custo Gasolina Custo Energia

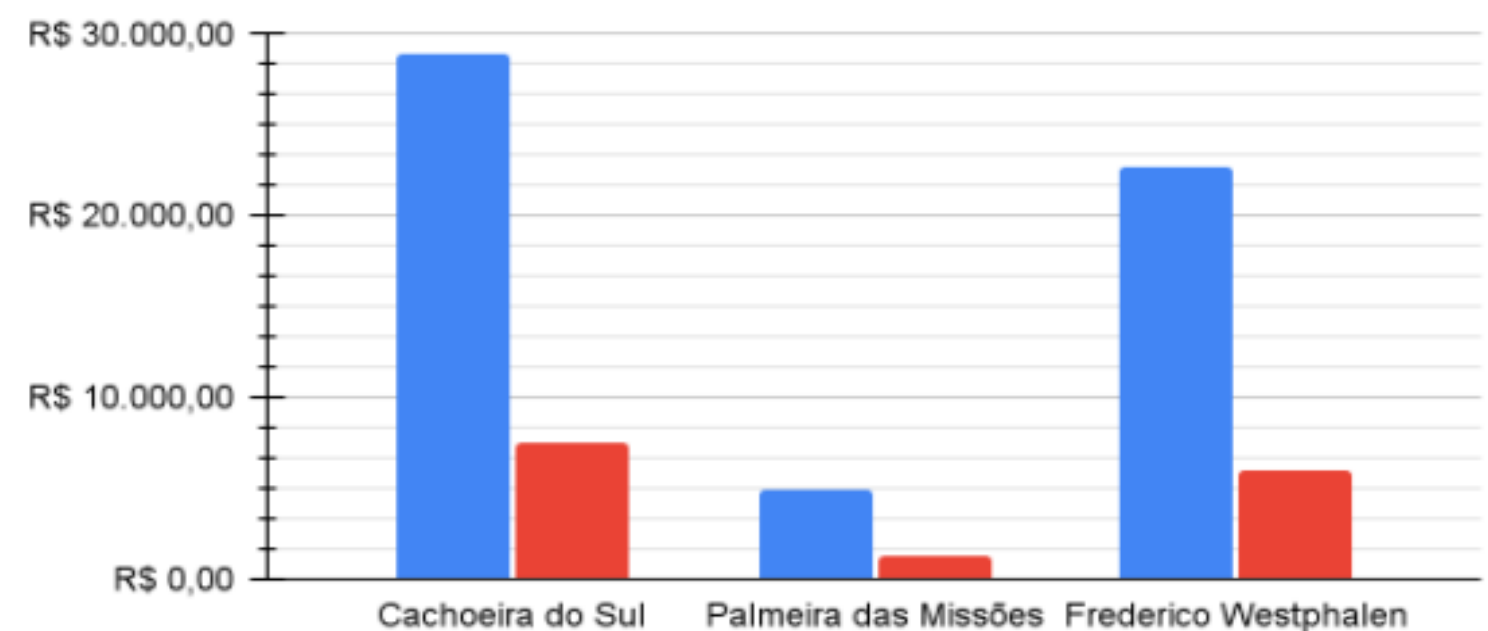

Fonte: Os Autores

Pressupondo que o valor da gasolina e quantidade de viagens entre Santa Maria e as sedes se mantenha constante, projeta-se que em io anos, o custo com gasolina total será de aproximadamente 546 mil reais.

\section{Gráfico ro - Gastos com Gasolina nos Próximos ıo anos}

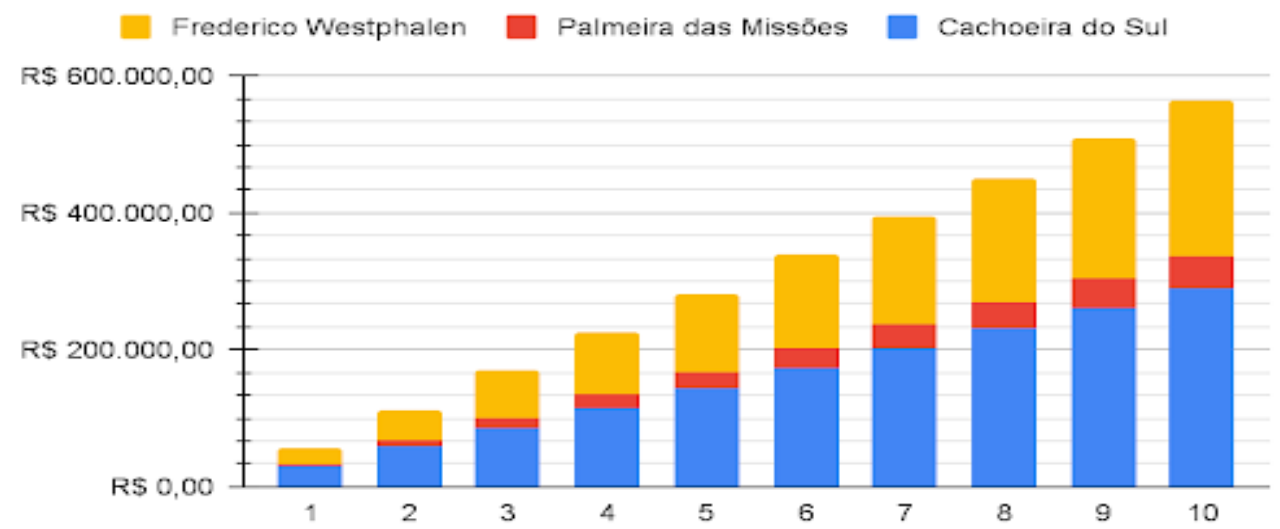

Fonte: Os Autores

Caso a fonte de combustível seja a energia elétrica, com a utilização dos veículos elétricos, assumindo que o custo da energia elétrica tenha um aumento de 
Iо\% ao ano, ao fim de ro é previsto que sejam gastos 234,5 mil reais para o carregamento dos veículos elétricos. Esses valores podem ser verificados no gráfico a seguir.

\section{Gráfico II - Gastos com Eletricidade nos Próximos io anos \\ Frederico Westphalen Palmeira das Missões Cachoeira do Sul}

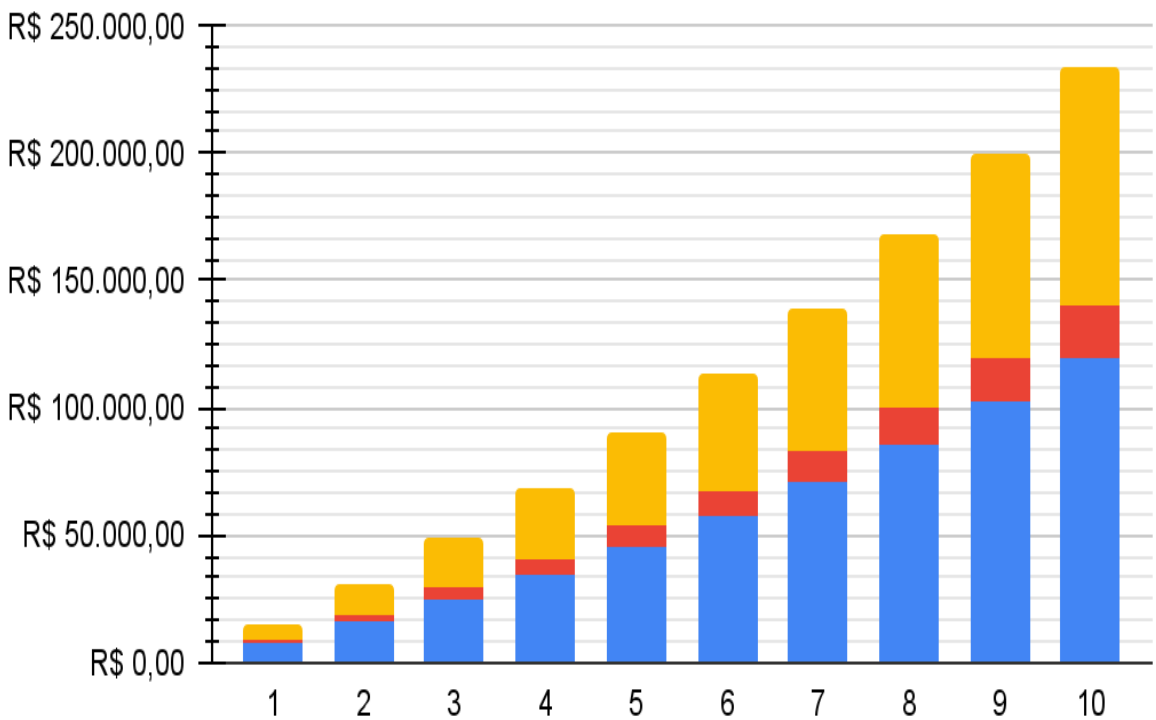

Fonte: Os Autores

Mesmo realizando a comparação em um caso desfavorável ao carro elétrico, em que o valor da eletricidade cresce a uma taxa de Io\% ao ano e o valor da gasolina se mantém estável, é perceptível a diminuição dos custos de combustível com a utilização dos veículos elétricos. O gráfico abaixo mostra isso ano a ano, chegando ao final do décimo ano com uma diferença de custos de aproximadamente 330 mil reais.

Gráfico 12 - Comparativo entre Gasolina e Eletricidade por Io anos

Frederico Westphalen

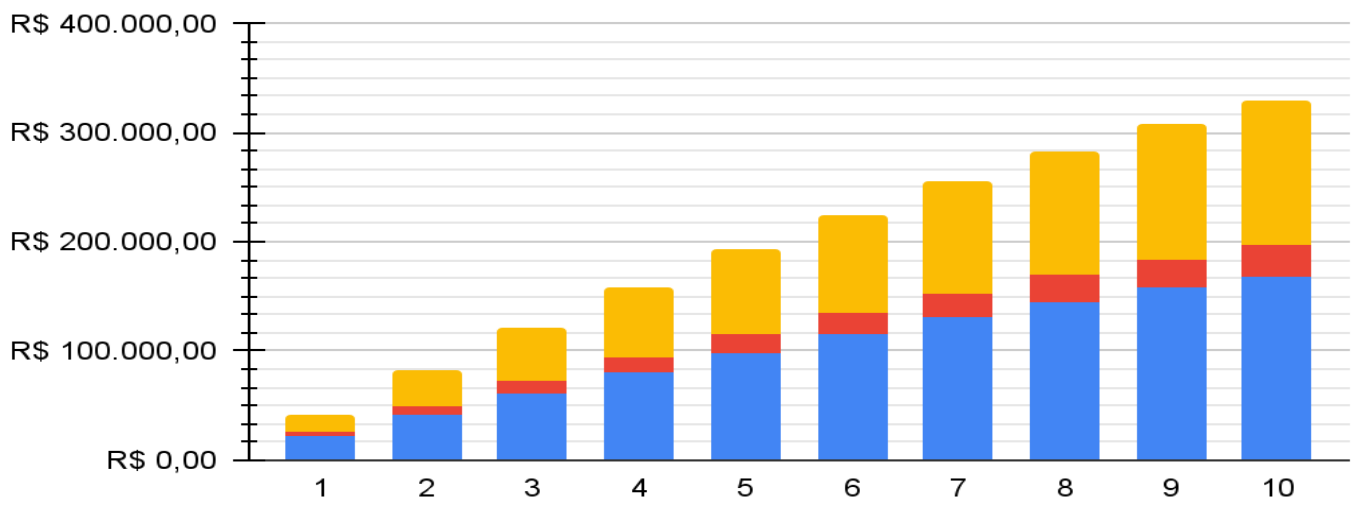

Fonte: Os Autores 
Além da vantagem econômica, a vantagem com relação a diminuição do $\mathrm{CO}_{2}$ gerado também foi projetada. Estima-se que ao final de ro anos, mais de 215 toneladas de dióxido de carbono deixarão de ser lançadas na atmosfera como pode ser visto através do gráfico a seguir.

Gráfico 13 - Emissão de Carbono em io anos

\section{Frederico Westphalen Palmeira das Missöes Cachoeira do Sul}

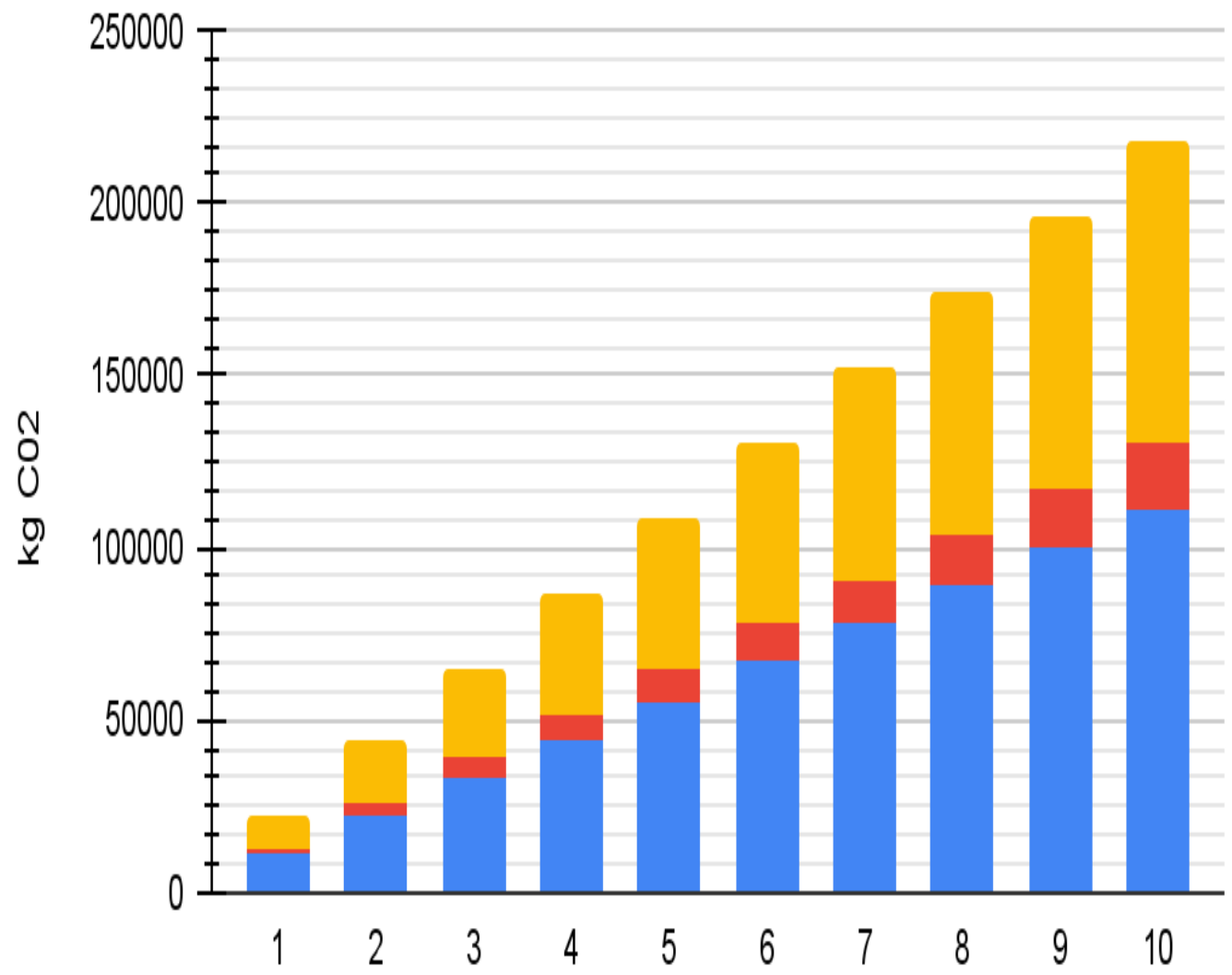

Fonte: Os Autores

Os valores utilizados para as simulações foram conservadores para o veículo elétrico, pressupondo generosos aumentos da tarifa de energia elétrica e otimistas para o veículo a combustão, não considerando aumento no valor da gasolina, e levando em consideração uma autonomia de $16 \mathrm{~km} / 1$ que é considerada alta. Mesmo neste cenário, o veículo elétrico se demonstrou uma ótima alternativa e como as viagens são realizadas, majoritariamente no período diurno, não há problema quanto ao sobrecarregamento da rede, visto que os veículos podem recarregar durante o período noturno, fora da ponta. 
Revista Ibero- Americana de Humanidades, Ciências e Educação- REASE open $\odot$ access

\section{ORÇAMENTO}

Definido os modelos os modelos de eletropostos e os veículos elétricos que serão adquiridos, é possível elaborar um orçamento base que contemple a construção das 3 estações de carregamento (Cachoeira do Sul, Palmeira das Missões e Frederico Westphalen) e a aquisição de 4 veículos elétricos, um para cada campus. O orçamento simplificado é demonstrado na tabela abaixo.

Tabela 08 - Orçamento Inicial

\begin{tabular}{|c|c|c|c|c|}
\hline Item & Quantidade & Preço & Total & Descrição \\
\hline Carro Elétrico & 4 & $\operatorname{RS} 259.990,00$ & RS 1.039.960,00 & Nissan Leaf \\
\hline Carregador & 3 & $R \$ 205.000,00$ & $\mathrm{R} \$ 615.000,00$ & $\begin{array}{c}\text { ABB Terra } 54 \text { DC Fast } \\
\text { Charger }\end{array}$ \\
\hline Cobertura & 3 & $R \$ 12.000,00$ & $\operatorname{R} \$ 36.000,00$ & Estrutura metálica \\
\hline Pavimentação & 3 & $\operatorname{R} \$ 5.000,00$ & $\operatorname{RS~} 15.000,00$ & $\begin{array}{l}\text { Blocos de concretos e } \\
\text { cimento }\end{array}$ \\
\hline Materiais de Obra & 3 & $\mathrm{R} \$ 4.000,00$ & $R \$ 12.000,00$ & $\begin{array}{l}\text { Condutores, iluminação, } \\
\text { equipamentos de proteção }\end{array}$ \\
\hline Mão-de-Obra & 3 & $\mathrm{R} \$ 8.000,00$ & $\mathrm{R} \$ 24.000,00$ & $\begin{array}{l}\text { Montagem dos blocos de } \\
\text { concreto, instalação elétrica }\end{array}$ \\
\hline Marketing & 1 & $\operatorname{R} \$ 2.000,00$ & $R \$ 2.000,00$ & $\begin{array}{l}\text { Divulgação para a } \\
\text { sociedade }\end{array}$ \\
\hline & Total & & & $1.743 .960,00$ \\
\hline
\end{tabular}

Fonte: Os Autores

Para a construção da infraestrutura que abrigará o posto de recarga, são levados em consideração no orçamento sua cobertura e pavimentação, bem como os materiais de obras, tanto elétricos quanto civis, e o custo de mão de obra para essa empreitada. 
O orçamento também abrange um valor a ser investido em marketing, para divulgação do projeto para o meio acadêmico e para a população que vive em torno das cidades sedes.

\section{CRONOGRAMA}

O cronograma básico do projeto é dividido entre as sedes, contendo ainda um tópico geral. Os eletropostos serão construídos em sequência, começando pelo de Cachoeira do Sul, depois o de Palmeira das Missões e finalizando com a construção do eletroposto de Frederico Westphalen. Segundo o cronograma, todos os eletropostos estarão em funcionamento até o mês de fevereiro de 2022. A construção do eletroposto leva em consideração a sua pavimentação, construção da cobertura, sua instalação elétrica e a montagem da estação de recarga.

Um processo importante contemplado no cronograma é o estudo de resultados, que envolve os diversos artigos, trabalhos de pesquisa, trabalhos de conclusão de curso que serão desenvolvidos a partir da infraestrutura criada.

\section{Tabela o9 - Cronograma}

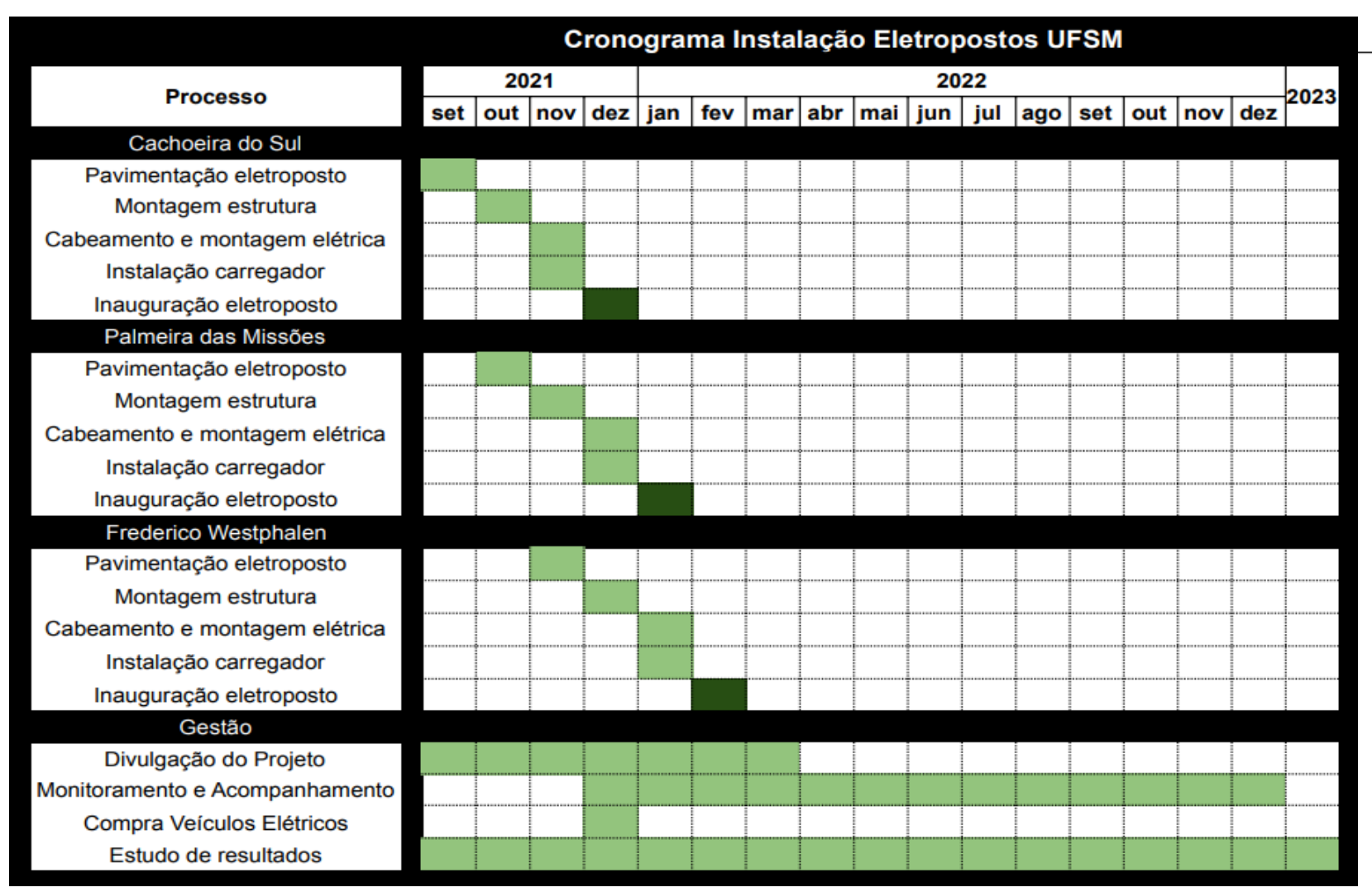

Fonte: Os Autores 


\section{Io. PARCEIRAS}

O referido projeto contará para sua execução com o apoio da Nissan, BYD, UFSM, CPFL/RGE.

\section{I0.I NISSAN}

Atualmente, algumas concessionárias da Nissan algumas concessionárias oferecem recargas rápida e gratuito, como Carrera Acelera (Avenida Brasil 1506, São Paulo/SP), Fuji (Avenida Sumaré, 24I, São Paulo/SP), San Diego São Conrado (Praça São Conrado, 20, Lote or - Rio de Janeiro/RJ), Iesa Porto Alegre (Avenida Wenceslau Escobar, 1204, Porto Alegre/RS), Barigui Parque (Rua Padre Agostinho, 3081, Curitiba/PR), Grand Premier (Sia Sul Trecho 02, Lotes 90 a 170, 90 Brasília/DF), e Globo Florianópolis (Rua General Liberato Bittencourt, I475 Loja I, Florianópolis/SC). [27]

A Nissan pretende com o projeto popularizar a utilização de veículos elétricos no interior e estimular a troca da frota de instituições federais, estaduais e municipais.

I0.2 Volvo

A Volvo está desenvolvendo estudos para desenvolvimento de ônibus elétricos. As pesquisas no Centro de desenvolvimento de Curitiba (PR), envolvem cadeia de fornecedores para peças que serão fabricadas localmente, aplicações alternativas e reciclagem das baterias após o uso nos veículos.

Tendo em vista a demanda de transporte público em cidades universitárias, a participação da Volvo no projeto visa estimular empresas locais de transporte urbano a substituir a frota por veículos elétricos. A contrapartida da empresa Volvo no projeto é um ônibus Volvo 7900 Eletric.

\subsection{CPFL / RGE}

A CPFL Energia, um dos maiores grupos privados do setor elétrico brasileiro, estima que o Brasil precisará de 80 mil eletropostos públicos até 2030 para acompanhar o ritmo de crescimento do mercado de veículos elétricos nacional. Para impulsionar o mercado de veículos elétricos e desenvolver uma nova cadeia de valor 
no Brasil, a CPFL Energia propõe a criação de uma estratégia nacional em torno da mobilidade elétrica.

A participação da CPFL/RGE no projeto visa fomentar a criação de eletropostos no interior do RS e estimular a circulação de veículos elétricos. Com os dados obtidos neste projeto, será possível prever a necessidade de melhorias no sistema de distribuição para atender esta demanda.

\section{CRITÉRIO DE INOVAÇÃO}

O Brasil é um país de dimensões continentais, sendo hoje a $12^{\circ}$ maior economia do mundo, porém sua infraestrutura de recarga não condiz com sua grandeza. Quando analisamos o mapa do Brasil no site PlugShare, fica evidente a concentração das estruturas de recargas em grandes centros urbanos, o que desmotiva os consumidores a adquirir veículos elétricos, pois caso tenham que se distanciar dos grandes centros, não terão opções para recarregar seu veículo. Nesse contexto se inclui a Universidade Federal de Santa Maria, localizada no interior do Rio Grande do Sul, nas regiões centro e noroeste do estado, com estrutura de recarga pública quase inexistente, possuindo estações de carregamento apenas em Santa Maria.

Quando filtramos por postos de carregamento rápido, a situação é ainda mais deficitária, sendo que hoje, existe apenas um ponto de carregamento rápido público em todo o Estado.

Os eletropostos que serão construídos nos campus sedes da UFSM terão uma grande importância regional, pois serão os primeiros das regiões centro e noroeste do estado rio grandense, constituindo a primeira eletrovia de recarga rápida em solo gaúcho.

A partir da implementação, os mais de I milhão de moradores dessa região serão apresentados a essa tecnologia, tendo acesso aos pontos de recarga incentivando a aquisição de veículos elétricos, possibilitando ainda a criação de diversos projetos envolvendo o setor público a fim de fomentar o crescimento da capacidade da eletrovia, demonstrando aos gestores públicos seus impactos positivos.

Sendo eletropostos de recarga rápida com controle da UFSM, os dados que serão coletados poderão ser divulgados e distribuídos para estudos de perfil de recarga e eficiência, contribuindo ainda mais para o desenvolvimento dessa tecnologia 
gerando diversos trabalhos de pesquisa na área. Dessa forma o projeto demonstra sua capacidade de inovação.

\section{RESULTADOS ESPERADOS}

Os resultados esperados são diversos, além de impactar os Objetivos de Desenvolvimento Sustentável citados no item 3.I da proposta do presente artigo, esperasse que o presente projeto possa introduzir futuras pesquisas para implantação da Eletrovia na UFSM, além de ser um pontapé inicial, para futuras pesquisas no âmbito da eletromobilidade em geral.

Além disso, caso o projeto se desenvolva realmente, esperasse que a eletromobilidade traga maior eficiência energética, por reduzir emissões de GEE no ciclo de vida e por não emitir poluentes atmosféricos no escapamento dos veículos, dentre tantos outros resultados já citados anteriormente, como a redução da emissão de $\mathrm{CO}_{2}$, incentivo a população local para aquisição de carros elétricos, com a implementação da infraestrutura adequada, além de propiciar aos alunos da universidade a oportunidade de se realizar diversas pesquisas a fim de otimizar e melhorar a eletromobilidade atual.

Outro resultado esperado é no âmbito industrial, pois com o crescimento do consumo de carros elétricos, as indústrias terão maior demanda de trabalho, logo, há um maior número de vagas de empregos disponíveis, assim demonstrando novamente a importância do presente projeto, atual e futuramente.

\section{CONCLUSÃO}

Apesar dos grandes desafios que ainda são obscuros frente à eletromobilidade, referente a tecnologia, regulamentação, infraestrutura e economia, é irrefutável a contribuição da eletromobilidade oferecida ao planeta e ao bem estar da população.

Sendo que essas obscuridades poderão ser sanadas em breve pelos pesquisadores do presente e do futuro, mas um estudo preliminar, contendo uma estimativa de preço, 
de rota, de cronograma, de impacto, etc..., serão de suma importância a fim de contribuir para a implantação da eletromobilidade no cotidiano.

Portanto, o presente projeto prevê as cidades sedes que serão contempladas com um carregador para os veículos, analisando a população, a distância até outro ponto de recarga, analisando também os trajetos entre os campus, Porto Alegre e cidades ao redor, analisando os modelos de veículos elétricos atualmente utilizados no país, os pontos de recarga, a influência desses pontos frente a micro e macro região, o impacto social, com custos, $\mathrm{CO}_{2}$ gerado, entre outros, sendo realizado também um estudo frente ao orçamento e sendo possível também fazer uma estimativa com relação ao cronograma do projeto.

Concluiu-se ao longo do projeto que os benefícios seriam inúmeros frente aos custos atuais, tendo um grande impacto nas sedes, influenciando a população a adquirir mais VE's (Veículos Elétricos), podendo se locomover a qualquer cidade do estado devido também a distribuição dos campus da UFSM. No projeto foi determinado um veículo específico para a universidade adquirir, devido ao fato de a mesma já possuir um modelo deste escolhido.

Portanto, a aplicação do projeto ficou orçado em cerca de $\mathrm{R} \backslash \$ 1.743 .960$,oo, levando em consideração os valores atuais, e sendo este apenas um estudo preliminar. E ficou previsto também um cronograma, em que as obras demorariam cerca de 6 meses e o acompanhamento dos impactos, resultados e estudos para melhorias, previstos para mais dois anos de análise.

Assim, o presente estudo, fez uma análise preliminar, a fim de inicializar este grande projeto que terá impactos significativos para o estado, para a universidade e para a comunidade em geral, incentivando a expansão da eletromobilidade.

\section{REFERENCIAS}

INSTITUTO BRASILEIRO DE GEOGRAFIA E ESTATÍSTICA (IBGE).

Produto Interno Bruto. Disponível em: https://www.ibge.gov.br/explica/pib.php. Acessado em: os de mai. de 202I. 
REDAÇÃO AB. Frota nacional soma 40 mil veículos elétricos e híbridos. AUTO BUSINESS.

https://www.automotivebusiness.com.br/inovacao/658/frota-nacional-soma-40mil-veiculos-eletricos-e-hibridos. Acessado em: 04 de jun. de 202I.

DETRAN-RS. Frota. Disponível em: https://www.detran.rs.gov.br/frota5bd4fi628347o. Acessado em: os de jun. de 202i.

Plugshare. Disponível em: https://www.plugshare.com/. Acessado em: io de jun. de 2021.

[5] BRAGA. PAULO R., No mundo, 2,6\% dos carros vendidos são eletrificados. AUTO BUSINESS. Disponível em: https://www.automotivebusiness.com.br/inovacao/667/no-mundo-26-dos-carrosvendidos-sao-eletrificados. Acessado em: I2 de jun. de 2021.

MAROCHI. VALÉRIO M., Afinal, o que é eletromobilidade? Blog - STI. Disponível em: https://www.senaipr.org.br/tecnologiaeinovacao/blog/afinal-o-quee-eletromobilidade-I-36287-426950.shtml. Acessado em: io de jun. de 2021.

Montagner. Milton Oliveira e R., A instalação da Universidade de Santa Maria. Conexão UFSM. Disponível em: http://coral.ufsm.br/revista/numeroo2/registroo4.html. Acessado em: i6 de jun. de 2021.

UFSM. UFSM em Números. Disponível em: https://portal.ufsm.br/ufsm-emnumeros/publico/index.html. Acessado em: is de mai. de 202I.

UFSM. Painel de alunos. Disponível em: https://portal.ufsm.br/ufsm-emnumeros/publico/painel.html;jsessionid $=4 f_{97} d 905 \mathrm{~d} 8 \mathrm{bf6} 99 \mathrm{f}_{345} \mathrm{cfob} 745$ a3 ?categoria $=$ IoI . Acessado em: is de jun. de 2021.

UFSM. UFSM na mídia. Disponível em: http://coral.ufsm.br/midia/?p=20132. Acessado em: 20 de jun. de 202I. 
Assessoria de Comunicação do Gabinete do Reitor. UFSM e RGE Sul inauguram

Usina de Microgeração Solar Fotovoltaica. Disponível em: https://www.ufsm.br/2018/ro/3I/ufsm-e-rge-sul-inauguram-usina-de-microgeracaosolar-fotovoltaica/. Acessado em: 2i de jun. de 202I.

ABB. Terra 94/124/184 UL Product guide. Disponível em: https://search.abb.com/library/Download.aspx?DocumentID=9AKKIo799IA42468 LanguageCode=en\&DocumentPartId=\&Action=Launch . Acessado em: 25 de jun. de 2021.

Plataforma Agenda 2030. Conheça a Agenda 2030. Disponível em: http://www.agenda2030.org.br/sobre/. Acessado em: 24 de jun. de 2021.

Pacto Global - Rede Brasil. OBJETIVOS DE DESENVOLVIMENTO SUSTENTÁVEL (ODS). Disponível em: https://www.pactoglobal.org.br/ods. Acessado em: ro de jun. de 202I.

[15] Saavedra Muñoz, Matilde.; Alvarez Villa, Diego.; Alejandro Sánchez Wilches,Elkin Asdrúbal. Diseño, construccion y puesta en marcha de ecoelectrolineras. http://repository.unipiloto.edu.co/handle/20.500.12277/5045. Acessado em: 25 de jun. de 202I.

Governo do Brasil. Fontes de energia renováveis representam $83 \%$ da matriz elétrica brasileira. Disponível em: https://www.gov.br/pt-br/noticias/energia-minerais-ecombustiveis/2020/ol/fontes-de-energia-renovaveis-representam-83-da-matrizeletrica-brasileira. Acessado em: io de jun. de 202I.

Empresa de Pesquisa Energética. Matriz Energética Brasileira. Disponível em: https://www.epe.gov.br/pt. Acessado em: i7 de jun. de 2021. 
[18] Jordan Business Magazine. Energia renovável: projetos que foram destaque em 2016. Disponível em: https://www.temsustentavel.com.br/energia-renovaveldestaque-em-2016/. Acessado em: I8 de jun. de 2021.

Unipiloto. Disponível em: http://repository.unipiloto.edu.co/. Acessado em: i9 de jun. de 202I.

Gauto, Marcelo. Adaptado de Union Of Concerned Scientists: Cleaner Cras From Cradle to Grave, 2015. Acessado em: I7 de jun. de 2021.

INSTITUTO BRASILEIRO DE GEOGRAFIA E ESTATÍSTICA (IBGE). População. Disponível em: https://www.ibge.gov.br/explica/pib.php. Acessado em: 20 de mai. de 202I.

I Carros. Ficha técnica Nissan LEAF 40kWh (Aut) 2020. Disponível em: https://www.icarros.com.br/nissan/leaf/ficha-tecnica. Acessado em: 26 de jun. de 2021.

Zolin, Deni. Posto para recarregar carros elétricos na UFSM deve ficar pronto em janeiro. Diário SM. Disponível em: https://diariosm.com.br/colunistas/colunistasdo-site/deni-zolin/posto-para-recarregar-carros-el\%C3\%A9tricos-na-ufsm-deveficar-pronto-em-janeiro-I.2289002. Acessado em: 23 de jun. de 202I.

ABB. Carregadores rápidos Terra EV. Disponível em: https://new.abb.com/evcharging/products/car-charging/dc-fast-chargers. Acessado em: I2 de jun. de 202I. AutoPapo. Preço da gasolina no Brasil: onde está a mais cara? E a mais barata? Disponível em: https://autopapo.uol.com.br/noticia/preco-gasolina-brasil/. Acessado em: 23 de jun. de 2021.

UFSM, Pro Infra. Núcleo de Transporte. Disponível em: https://www.ufsm.br/proreitorias/proinfra/nucleo-de-transporte/. Acessado em: 25 de jun. de 202I. 
NISSAN. Site Oficial Nissan. Disponível em:

https://www.nissan.com.br/veiculos/modelos/leaf/autonomia-recarga.html.

Acessado em: 23 de jun. de 2021. 